\title{
Gender attitude towards environmental protection: a comparative survey during COVID-19 lockdown situation
}

\author{
S. A. Dhenge ${ }^{1}$ (D) S. N. Ghadge ${ }^{1} \cdot$ M. C. Ahire ${ }^{1} \cdot$ S. D. Gorantiwar ${ }^{1} \cdot$ M. G. Shinde ${ }^{1}$
}

Received: 4 November 2020 / Accepted: 25 November 2021 / Published online: 13 January 2022 (c) The Author(s), under exclusive licence to Springer Nature B.V. 2021

\begin{abstract}
Attitude towards environmental protection is a crucial component in environmental safeguard psychology. It is a psychological tendency expressed by evaluating the environmental gender attitude with favour or disfavour. This study aimed to compare the attitude level of male and female trainees towards environmental protection based on personal, psychological and sociocultural variables by using an ex post facto research design. The research population was composed of the trainees $(N=177)$ who participated in the online training programmes organized from April 07 to May 31, 2020, by the Centre for Advanced Agricultural Science and Technology (CAAST) for Climate Smart Agriculture and Water Management (CSAWM), MPKV, Rahuri, Maharashtra, during COVID-19 lockdown period. In this study, an online survey method was used. The research instrument was a well-designed and structured online questionnaire using a Google Form consisting of two sections. The first section consisted of 11 independent variables of personal, psychological and sociocultural characteristics. The second section consisted of 17 environmental attitude questions focusing on closed structure questions with a five-point Likert scale, i.e. Strongly Agree to Strongly Disagree. The results revealed that age, training received, membership of environmental societies or organizations, courses taught, waste management and social media use significantly affect the trainees' attitudes to environment protection. The female respondents had a favourable environmental attitude when compared with the male respondents. Therefore, the study concluded that a set of factors influences the gender attitude of the online trainees. These factors alone cannot change trainees' attitudes towards environmental protection. Accordingly, necessary and appropriate conditions should be provided to change the attitude of male trainees for environmental protection. Sustained support is necessary to efficiently understand the role of gender in environment protection through government policies, social media, policymakers, scientists, extension workers, research organizations, various training programmes, participation of students and faculty in the environmental cleanliness drive and awareness programs, etc.
\end{abstract}

Keywords Gender attitude · Environmental protection · Comparative survey · COVID-19

S. A. Dhenge

sevak1989@rediffmail.com

1 Centre for Advanced Agriculture Science and Technology for Climate Smart Agriculture and Water Management, Mahatma Phule Krishi Vidyapeeth, Rahuri, Dist., Ahmednagar, Maharashtra 413722, India 


\section{Introduction}

World over, people are facing several environmental issues such as the rapid growth of industrialization, deforestation, excessive use of non-degradable substances, alarming population growth, rural areas demanding urban conveniences, endless urbanization (Li et al. 2005), excessive use of vehicles, globalization and liberalization (Davis 1998; Baykal and Baykal 2008). While humanity desires a luxurious life, it does not consider the environmental problems in its concepts, thinking, behaviour and achievements (Watson and Halse 2005; Negev et al. 2010). This approach to life urgently demands a thorough education to internalize the importance of sustainable environmental protection on a sustainable basis. Environmental safeguard is one of the goals in the sustainable development agenda (UN, 2018). It seeks an increasing commitment from the academics and policymakers (UN 2016; Baker 2016; Robinson 2004), from the environmental, economic and social perspectives (Giddings et al. 2002). Sustainable development and preservation of natural resources are possible with grassroots and local communities (Rauch 2002; Giddings et al. 2002). Nowadays, waste management problems prevail more in urban areas than in rural areas. The increasing waste disposed of without classification creates environmental pollution (Bin et al., 2019), and it is a big challenge to the sustainable development of any society (Bin et al., 2019). For proper management, in this context, a wide variety of programmes, institutional efforts, awareness activities and research are being intensively undertaken for the past few years (Huhtala 1999; Barr et al. 2001; Tonglet et al. 2004). In 2015, the total accumulation of municipal solid waste was 3270 million tons, contributing to $70 \%$ of waste production among East-Asian countries (NBSC 2016). India's municipal solid waste (MSW) will increase significantly due to its efforts to attain an industrialized-nation status by 2020 (Gidde et al. 2008; Gupta and Arora 2016; Sahu et al. 2014; Sharholy et al. 2008). The household is one of the major sources of municipal solid waste (Rada et al., 2013). According to the Central Pollution Control Board (CPCB 2016), urban India produced 62 Mt of MSW in 2015, or 169,864 t/day or $450 \mathrm{~g} /$ capita/day. About $82 \%$ (50 Mt) of MSW was collected. The remaining $18 \%$ (12 Mt) consisted of litter and air pollution. These are the major causes of environmental damage and dilute people's immune systems. During 1947, 2001 and 2011, the urban solid waste accumulated was 31 and $48 \mathrm{Mt}$, respectively (Rawat et al., 2013; Singh et al., 2011). At this rate, the total urban MSW $165 \mathrm{Mt}, 230 \mathrm{Mt}$ and 436 Mt will be during 2030, 2041 and 2045, respectively (Annepu 2012; WtR 2014). From this perspective, the management of natural resources focusing on environmental protection must incorporate the local knowledge, experience, values and people's perception. Therefore, waste sorting and recycling of wastewater are of utmost importance joint efforts. It can help reduce 30-40\% waste, reproduce new goods and address the existing pressures on scarce water supplies (Bin et al., 2019; Chen et al., 2013). But it is not easy to understand the social environment in relation to the ecological milieu (Silva et al., 2013). However, the local communities have been living since ages with the surrounding environment, and they highly depend on the natural resources for food, fuelwood (An et al. 2002; Pote et al. 2006), medicinal herbs (Dzerefos and Witkowski 2001), honey and other products (Fabricius and Burger 1997). Therefore, they understand environmental issues better for they possess traditional ecological knowledge, which helps achieve environmental protection, biodiversity conservation (Berkes et al., 2000; Song et al. 2010), minimizing the impact on the environment (Venter et al. 2016) and coping with the degradation of natural ecosystems (Potapov et al. 2011). It is worth noting here that Environmental Attitudes (EA) are a psychological tendency expressed by evaluative responses to the natural environment 
with some degree of favour or disfavour (Milfont and Duckitt, 2004). Environmental attitudes are a latent construct; therefore, we cannot observe them directly. We can only infer it from overt responses (Himmelfarb, 1993). We can also use direct self-report methods or implicit measurement techniques (Krosnick, Judd, \& Wittenbrink, 2005). This study seeks to determine the positive and negative attitudes of the male and female respondents who play a significant role in the conservation of the environment and adoption of eco-friendly practices with specific objectives which are: (1) to study the personal, psychological, communicational and sociocultural characteristics of the trainees of online training programs of COVID-19 lockdown period of April 07 to May 31, 2020, (2) to study and compare the attitude level of male and female trainees towards environmental protection, (3) to determine the relationship between personal, psychological, communicational and sociocultural characteristics of the trainees and attitude towards environmental protection.

This paper provides valuable information concerning ecological protection with a gender perspective that can be applied to other environmental management scenarios where individual attitudes are taken into consideration.

\subsection{Purpose of the research}

Men and women have various roles and responsibilities in our families, our societies and our cultures. They are involved in the management and conservation of biodiversity according to their perceived environmental protection experience. A positive attitude of gender is an essential factor concerning environmental activities. It has been contributing significantly to become conscious about the environmental problems and in finding solutions to them. Therefore, the importance of gender attitude should not be ignored while cogitating on environmental protection. From this point of view, it is necessary to understand environment-related problems and find appropriate solutions. Besides, the amount of research conducted on gender differences and attitudes towards environmental protection is relatively sparse. With this background, this paper examines the attitudes of the trainees towards environmental protection. The respondents of this study are the trainees who attended many online training programmes conducted by the Centre for Advanced Agricultural Technology for Climate Smart Agriculture and Water Management. Therefore, training received as a variable is helpful because it is one of the psychological components that can improve skills and change the human mindset. It is beneficial to students, faculty and policymakers to design and implement environmental protection programmes. Secondly, membership of environmental organizations/societies is another variable. From time to time, such organizations organize various environmental protection programmes, which are practical tools to conscientize the respective members. This investigation delves into such variables in its approach. This research is also important for students to sensitize and increase awareness of environment protection and set future researchers' trends in the supplementary field. The general aim of this investigation is to understand the gender differences and attitudes towards environmental protection. The following questions are addressed in the context of this general aim:

(1) What are the gender differences in attitudes towards environment protection?

(2) Is there any significant difference between the attitudes of gender towards environmental protection? 


\subsection{Theoretical Background}

\subsubsection{Gender differences in environmental concern}

Gender issues in environmental protection involve identifying the influence of gender roles, responsibilities and their relations to the environment's use, management and conservation. Women and men's roles in environmental protection vary from one country to another and within countries and cultures. It mainly depends on the knowledge, experience, awareness, needs, risk and vulnerabilities and decision-making power of the respective gender (Soma Chakrabarti 2020). Gender influences all aspects, including social, economic and health (Nierenberg, 2002). In the context of environmental concerns, it is a complex and multidimensional concept that can be defined as the extent of men and women emotionally and sensitively committed to environment-related problems and provide support to various environmental protection activities (Chenyang and Aaron, 2015). Gender refers to the socially constructed qualities of women and men in relation to norms, roles and relationships between women and men and the biological differences between males and females (Osterberg 1996). Gender difference as a social construct (Gilligan, 1982; Hustinx and Lammertyn, 2003) is a significant factor for formulating social policies and social welfare (Taniguchi, 2006).

\subsubsection{Attitude in environmental concern}

Attitude is how an individual feels towards someone, an object, an institution, a method, a subject, a thought, an idea, a situation or an event (Chauhan et al., 2017). An attitude is an approach to life. It reflects behaviour and determines the outcome, learned tendency, positive or negative feeling towards any psychological object. It influences our action, knowledge of a situation, feeling or emotion, tendency to respond, determinants of behaviour, mental and neutral state of readiness. The formation of environmental attitudes is more critical for attaining environmental sustainability (Müderrisoglu and Altanlar, 2011). There is an urgent need to achieve environmental sustainability by influencing the attitude of the people towards effective use and management of natural resources (Munasinghe 2020).

\subsection{Hypotheses}

A research hypothesis represents the relation between two or more measurable variables and tentative solutions to solve a problem (Ary et al. 1984). It is a conjectural statement of the relation between two or more variables (Kerlinger 1956). A formal statement presents an expected relationship between independent and dependent variables (Creswell 1994) and relational propositions (Kerlinger, 1956). It should help the researcher determine the implications of examining the stated relationship between two or more variables. With such claims in the attitudinal research, this investigation hypothesizes the following:

(1) Men and women possess differential, personal, socio-economic and psychological characteristics.

(2) Men and women have distinctive attitudes to environmental protection. 
(3) The individual, socio-economic and psychological attributes of men and women have a significant relationship with gender attitude.

\section{Method}

\subsection{Research model}

In this investigation, we have used a survey model. The responses were collected through the Google Form with a well-designed online tool during the COVID-19 lockdown period. It was necessitated by the World Health Organization (WHO) declaration that the COVID-19 outbreak was a global pandemic on March 11, 2020 (Cucinotta and Vaneli, 2020), which has affected all countries and territories of the world (Munasinghe, 2020). There is an urgent need to adopt sustainable environmental practices globally to meet the demand in the context of health facilities, food and water shortage and creating awareness during the COVID-19 pandemic as the situation arises in the future (Munasinghe, 2020). This investigation was conducted under the aegis of the World Bank Aided- Indian Council of Agricultural Research - National Agricultural Higher Education Project (NAHEP), New Delhi, at the Centre for Advanced Agricultural Science and Technology (CAAST) for Climate Smart Agriculture and Water Management (CSAWM), MPKV, Rahuri, the Social Sciences through the Agricultural Extension \& Communication. This centre has developed a model for organizing online training programmes during the COVID-19 lockdown period. It has been organizing several training programmes for strengthening Climate Smart Agriculture and Water Management practices. A survey model is a research approach that can describe an event in the past or present (Karasar, 2007).

\subsection{The Questionnaire}

As mentioned above, in this investigation, we used a structured online questionnaire consisting of 11 independent variables and 1 dependent variable. The dependent variables consisted of 17 environmental attitude questions. The 17 questions mainly consisted of closed structure questions with a five-point Likert scale, i.e. Strongly Agree, Agree, Undecided, Disagree and Strongly Disagree. In this article, we focused mainly on gender attitude answers to items about the environment. Accordingly, we designed a Google Form by discussing with subject experts and reviewing the research papers, policy papers and online survey websites. Following the suggestions received from the subject experts, we modified the form, which consisted of two parts. The first part consisted of the profile of the participants, communication and related psychological variables, while the second part consisted of 17 items concerning attitudinal statements about the environment. After the finalization of the online questionnaire, we undertook the actual survey.

\subsection{Study area and Selection of sample}

The World Bank Aided - Indian Council of Agricultural Research-National Agricultural Higher Education Project, New Delhi, has sponsored the Centre for Advanced Agricultural Science and Technology (CAAST) for Climate Smart Agriculture and Water Management (CSAWM), MPKV, Rahuri, Maharashtra, India. This centre has developed a model for organizing online training programmesduring the COVID19 lockdown period and has been organizing several training programmes in the 
thematic areas of Climate Smart Agriculture and Water Management. Accordingly, each training programme had a WhatsApp group of participants for the smooth conduct of the training programme. All the training-related information was shared through these groups. PG, PhD scholars, scientists and faculties from all over the country were trained in this online training. The online data were collected for this investigation from April 07 to May 31, 2020. During this period, this centre had organized 20 online training programmes of 3 days to 1-week durations. Through formulated WhatsApp groups, the online questionnaire was circulated. The participants were asked to fill in the online questionnaire form. After one month, we removed this questionnaire. Accordingly, we collected the trainee participants' data, i.e. PG, PhD students, scientists, subject experts and faculties, through an online Google Form during the COVID-19 lockdown period. The online trainee participants were considered for sampling. In all, the centre had received $177(N=177)$ trainees' responses. The responses consisted of 133 male and 44 female trainees. Thus, a total of $177(N=177)$ respondents were considered for this investigation.

\subsection{Research design}

This investigation quantitative research method was used with an ex post facto research design. The main aim of the ex post facto study is to determine the cause and effect of a relationship or association between two or more than two variables (Gay, Mills \& Airasian, 2011). A research design is the plan, structure and investigation strategy to answer research questions and control variance (Kerlinger, 1964). An ex post facto research design is used by researchers who do not directly control the independent variables and cannot be manipulated (Black, 1999). A research design is a plan or proposal to conduct research, which entails the intersection of philosophy, inquiry strategies and specific methods (Sivakumar et al., 2017). The ex post facto research is a systematic empirical inquiry. The researcher does not directly control the variables because their manifestations have already occurred or are inherently unmanipulable (Kerlinger, 1964). The literal meaning of ex post facto is 'from what is done afterwards'. The ex post facto design was applied to this investigation because the independent variables, the researcher cannot directly manipulate. After all, it is something that occurs directly in the field.

\subsection{Statistical tools}

The study was based on an online survey using a structured questionnaire. The data collected through Google Form include standard deviation, frequencies and percentages and were calculated for descriptive data.

\subsection{Variables}

Data on 13 independent variables and one dependent variable were collected. Seventeen items as dependent variables of environmental concern were used. The detailed information of the variables is presented in Table 1 . 


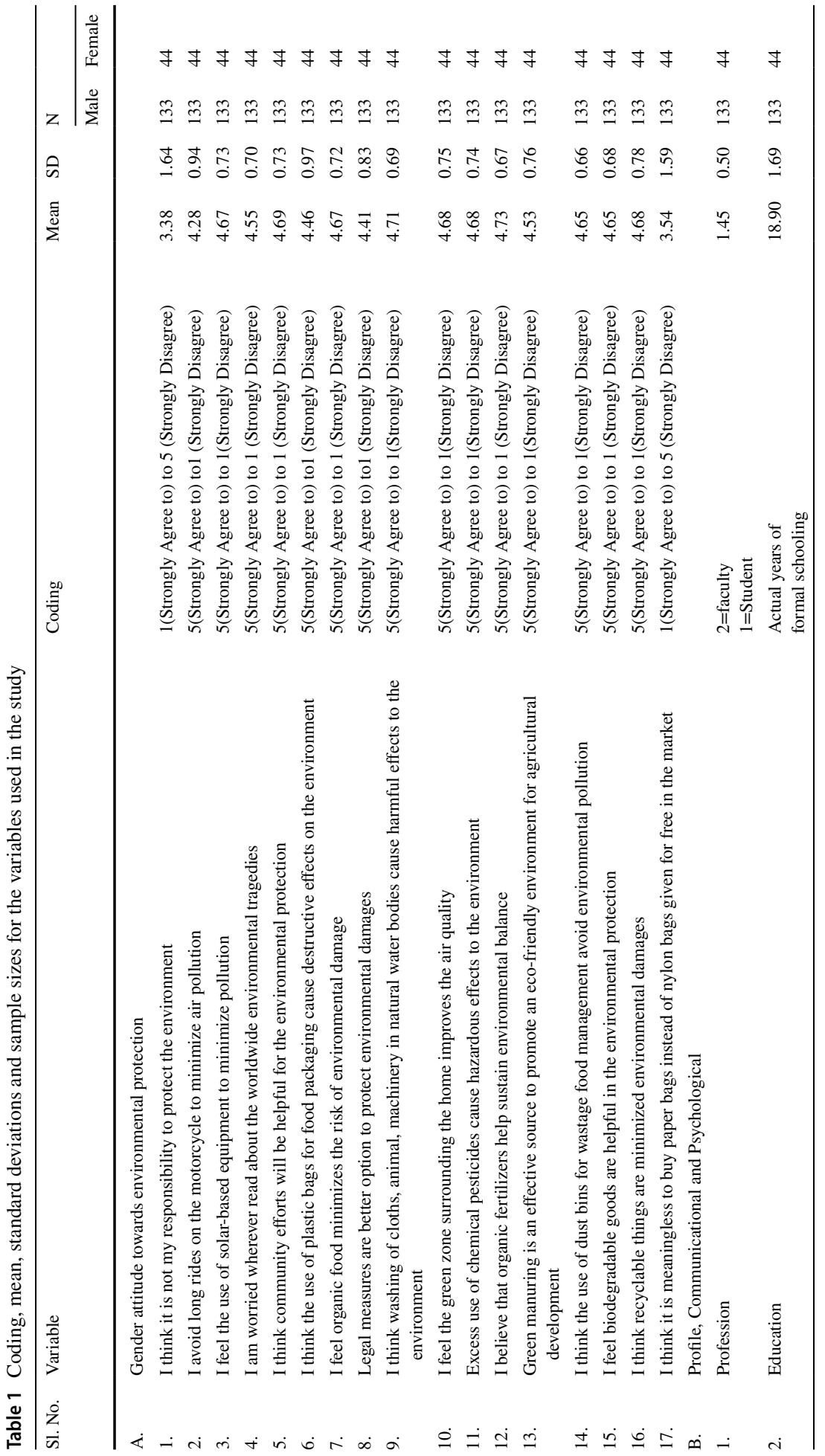




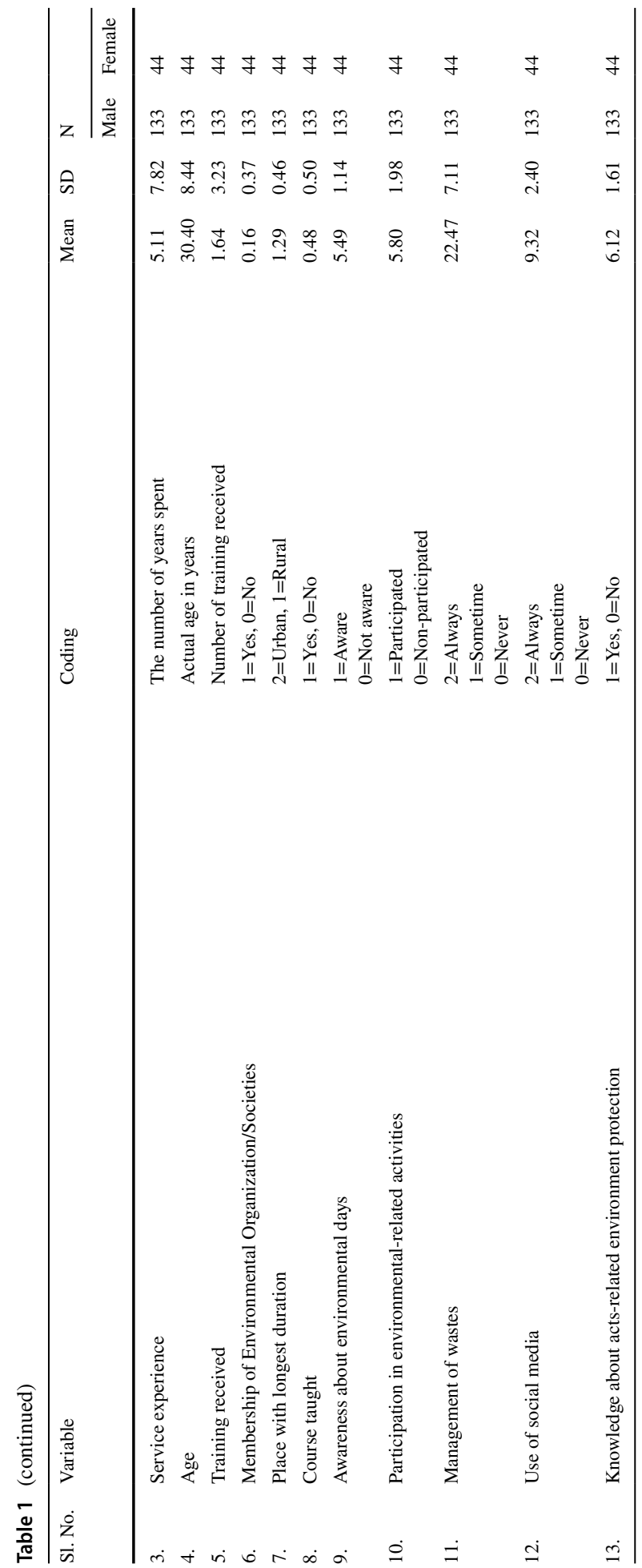


Table 2 Distribution of the respondents according to their profession

\begin{tabular}{lllcl}
\hline S1. No. & Category & \multicolumn{2}{l}{ Respondents } & \\
\cline { 3 - 5 } & & $\begin{array}{l}\text { Male } \\
(N=133)\end{array}$ & Female $(N=44)$ & Overall $(N=177)$ \\
& & $65(48.87)$ & $15(34.09)$ & $80(45.20)$ \\
1. & Faculty & $68(51.13)$ & $29(65.91)$ & $97(54.80)$ \\
2. & Student & $67(100.00)$ & $44(100.00)$ & $177(100.00)$ \\
& Total & $133(.49$ & 1.34 & 1.45 \\
& Average & 1.49 & &
\end{tabular}

\section{Results}

Table 2 reveals that more than half of the male $(51.30 \%)$ respondents were students, while $48.87 \%$ of the respondents were the faculty. In the case of female respondents, more than three-fifths $(65.19 \%)$ of the respondents were students, and about one-third $(34.09 \%)$ of the respondents were faculty. The combined data showed that a majority $(54.80 .00 \%)$ of the respondents were in the students, while $45.20 \%$ of the respondents were the faculty. The average professions of the male and female respondents were 1.49 and 1.34 , respectively. The combined average profession of the respondents was 1.45 .

Table 3 shows that more than half $(58.65 \%)$ male respondents were post-graduates, whereas more than one-third $(33.08 \%)$ and less than one-tenth $(7.52 \%)$ of the respondents were doctoral and graduate degree holders, respectively. The diploma holders were 0.75 $\%$ of the respondents. Similarly, $56.82 \%$ of the female respondents were post-graduates, while $34.09 \%$ were doctorates and $9.09 \%$ of respondents were graduate degree holders. There were no female participants with a diploma. At the overall level, $58.19 \%$ of the respondents were post-graduates, whereas one-third $(33.33 \%)$ and less than one-tenth (7.91\%) of respondents were doctorates and graduate degree holders, respectively. The percentage of diploma holders was 0.56 . The average education of the male and female respondents was 18.90 standards and 18.91 standards, respectively. At the overall level, the average education of the respondents was 18.90 standard.

Table 4 shows that less than half of the male $(41.35 \%)$ respondents were of middlelevel service experience. In contrast, one-third (39.10\%) and one-fifths (19.55\%) of the respondents belonged to less and more service experience, respectively. It was further

Table 3 Distribution of the respondents according to their education

\begin{tabular}{|c|c|c|c|c|}
\hline \multirow[t]{2}{*}{ Sl. No. } & \multirow[t]{2}{*}{ Degree } & \multicolumn{3}{|l|}{ Respondents } \\
\hline & & $\begin{array}{l}\text { Male } \\
(N=133)\end{array}$ & $\begin{array}{l}\text { Female } \\
(N=44)\end{array}$ & Overall $(N=177)$ \\
\hline 1. & Diploma & $01(0.75)$ & - & $01(0.56)$ \\
\hline 2. & Graduation & $10(7.52)$ & $04(9.09)$ & $14(7.91)$ \\
\hline 3. & Post-Graduation & $78(58.65)$ & $25(56.82)$ & $103(58.19)$ \\
\hline \multirow[t]{2}{*}{4.} & Doctorate & $44(33.08)$ & $15(34.09)$ & $59(33.33)$ \\
\hline & Total & $133(100.00)$ & $44(100.00)$ & 177 (100.00) \\
\hline
\end{tabular}


Table 4 Distribution of the respondents according to their service experience

\begin{tabular}{lllll}
\hline & $\begin{array}{l}\text { Average } \\
\text { Category (Yrs) }\end{array}$ & $\begin{array}{l}18.90 \\
\text { Respondents }\end{array}$ & 18.91 & 18.90 \\
\cline { 3 - 5 } & $\begin{array}{l}\text { Male } \\
(N=133)\end{array}$ & $\begin{array}{l}\text { Female } \\
(N=44)\end{array}$ & Overall $(N=177)$ \\
\hline 1. & Less (Up to 1.20) & $52(39.10)$ & $27(61.36)$ & $79(44.63)$ \\
2. & Medium (1.21 to 9.02) & $55(41.35)$ & $11(25.00)$ & $66(37.29)$ \\
3. & More (9.03 and above) & $26(19.55)$ & $06(13.64)$ & $32(18.08)$ \\
& Total & $133(100.00)$ & $44(100.00)$ & $177(100.00)$ \\
& Average & 5.78 & 3.07 & 5.11 \\
\hline
\end{tabular}

noticed that more than half of the female $(61.36 \%)$ respondents were with less service experience, followed by respondents with $25.00 \%$ and $13.64 \%$ belonged to the medium and more service experience category, respectively. At the overall level, $44.63 \%$ of the respondents belonged to the less service experience category. In contrast, more than onethird $(37.29 \%)$ and less than one-fifths $(18.08 \%)$ of the respondents had medium and more service experience, respectively. The average service experience of the male and female respondents was 5.78 years and 3.07 years, respectively. At the overall level, the average service experience of the respondents was 5.11 years.

It is noted from Table 5 that $81.20 \%$ of the male respondents belonged to the middle age group, followed by 17.30 and $1.55 \%$ of the respondents who belonged to the old and young age group, respectively. In the case of female respondents, more than fourfifths $(86.36 \%)$ of the respondents had a middle-age group, followed by 11.37 and $2.27 \%$ respondents belonged to the old and young group, respectively. At the overall level, 82.49 $\%$ of the respondents were of the middle age group, whereas 15.82 and $1.69 \%$ respondents belonged to the medium and young group, respectively. The average age of the male and female respondents was 31.33 years and 27.55 years, respectively. At the overall level, the average age of the respondents was 30.40 years.

It can be observed from Table 6 that more than two-fifths of the male $(48.12 \%)$ respondents did not receive any training, followed by 33.08 and $18.80 \%$ of the respondents who had received 1 to 3 and 4 and above training programmes, respectively. Regarding female respondents, more than half of the female $(52.27 \%)$ respondents did not receive any

Table 5 Distribution of the respondents according to their age

\begin{tabular}{lllll}
\hline S1. No. & Category (Yrs) & Respondents & \\
\cline { 3 - 5 } & & $\begin{array}{l}\text { Male } \\
(N=133)\end{array}$ & $\begin{array}{l}\text { Female } \\
(N=44)\end{array}$ & Overall $(N=177)$ \\
\hline 1. & Young (Up to 35) & $02(1.55)$ & $01(2.27)$ & $03(1.69)$ \\
2. & Middle (36 to 50) & $108(81.20)$ & $38(86.36)$ & $146(82.49)$ \\
3. & Old ( 51 and above) & $23(17.30)$ & $05(11.37)$ & $28(15.82)$ \\
& Total & $133(100.00)$ & $44(100.00)$ & $177(100.00)$ \\
& Average & 31.33 & 27.55 & 30.40 \\
\hline
\end{tabular}


Table 6 Distribution of the respondents according to their training received

\begin{tabular}{|c|c|c|c|c|}
\hline \multirow[t]{2}{*}{ S1. No. } & \multirow[t]{2}{*}{ Category (Score) } & \multicolumn{3}{|l|}{ Respondents } \\
\hline & & $\begin{array}{l}\text { Male } \\
(N=133)\end{array}$ & $\begin{array}{l}\text { Female } \\
(N=44)\end{array}$ & Overall $(N=177)$ \\
\hline 1. & No training & $64(48.12)$ & $23(52.27)$ & $87(49.15)$ \\
\hline 2. & 1 to 3 training & $44(33.08)$ & $13(29.55)$ & $57(32.20)$ \\
\hline \multirow[t]{3}{*}{3.} & 4 and above training & $25(18.80)$ & $08(18.18)$ & $33(18.64)$ \\
\hline & Total & $133(100.00)$ & $44(100.00)$ & $177(100.00)$ \\
\hline & Average & 1.62 & 1.68 & 1.64 \\
\hline
\end{tabular}

training, followed by 29.55 and $18.18 \%$ of the respondents who had received 1 to 3 and 4 and above training, respectively. Less than half (49.15\%) of the respondents did not receive any training at the overall level. However, 32.20 and $18.64 \%$ of respondents had attended 1 to 3 and 4 and above training programmes, respectively. The average training received by male and female respondents was 1.62 and 1.68, respectively. At the overall level, the average training received by the respondents was 1.64 .

It can be viewed from Table 7 that more than four-fifths of the male (84.96\%) respondents were not members of any environmental organization/society. In contrast, less than two-fifths $(15.04 \%)$ of the respondents were members of environmental organizations/ societies. In the case of female respondents, more than three-fourths $(79.55 \%)$ of the respondents were not members of any environmental organization/society, followed by $20.45 \%$ of the respondents who were members of environmental organizations/societies. At the overall level, $83.62 \%$ of the respondents did not have membership of any environmental organization/society, followed by $16.38 \%$ of the respondents who were members of environmental organizations/society. The average membership obtained by the male and female respondents in any environmental organization/society and the female respondents

Table 7 Distribution of the respondents according to their membership of environmental organizations/societies

Table 8 Distribution of the respondents according to their place with the longest duration

\begin{tabular}{lllll}
\hline S1. No. & Category & \multicolumn{2}{l}{ Respondents } & \\
\cline { 3 - 5 } & & $\begin{array}{l}\text { Male } \\
(N=133)\end{array}$ & $\begin{array}{l}\text { Female } \\
(N=44)\end{array}$ & Overall $(N=177)$ \\
\hline 1. & Member & $20(15.04)$ & $09(20.45)$ & $29(16.38)$ \\
2. & Not member & $113(84.96)$ & $35(79.55)$ & $148(83.62)$ \\
& Total & $133(100.00)$ & $44(100.00)$ & $177(100.00)$ \\
& Average & 0.15 & 0.20 & 0.16 \\
\hline
\end{tabular}

\begin{tabular}{lllll}
\hline S1. No. & Category & \multicolumn{2}{l}{ Respondents } & \\
\cline { 3 - 5 } & & $\begin{array}{l}\text { Male } \\
(N=133)\end{array}$ & $\begin{array}{l}\text { Female } \\
(N=44)\end{array}$ & Overall $(\mathrm{N}=177)$ \\
\hline 1. & Rural & $96(71.18)$ & $29(65.91)$ & $125(70.62)$ \\
2. & Urban & $37(27.82)$ & $15(34.09)$ & $52(29.38)$ \\
& Total & $133(100.00)$ & $44(100.00)$ & $177(100.00)$ \\
& Average & 1.28 & 1.34 & 1.29 \\
\hline
\end{tabular}


was 0.15 and 0.20 , respectively. At the overall level, the average membership of the respondents in any environmental organization/society was 0.16 .

A quick look at Table 8 shows that a little less than three-fourths $(71.18 \%)$ of the male respondents lived in rural areas, whereas more than one-fourths $(27.82 \%)$ of the respondents were living in urban areas. More than three-fifths (65.91\%) of the female respondents had lived for the longest duration in rural areas, followed by $34.09 \%$ of the respondents who had the longest duration in urban areas. At the overall level, 70.62 and $29.38 \%$ of the respondents have the longest duration in rural and urban areas, respectively. The average longest duration of the male and female respondents was 1.28 and 1.34, respectively. At the overall level, the average area with the longest duration of the respondents was 1.28.

It can be seen from Table 9 that $66.15 \%$ of the male faculty had not taught any course on environmental aspects, followed by $33.85 \%$ of the male faculty who taught courses on environmental aspects. While $66.67 \%$ of the female faculty had not taught any course on environmental aspects, $33.33 \%$ of the female faculty taught courses on environmental aspects. At the overall level, $66.25 \%$ of the faculty had not taught any course on environmental aspects, followed by $33.75 \%$ of the faculty who had taught courses on environmental aspects. The average environmental courses taught by the male and female faculty were 0.48 and 0.48 , respectively. At the overall level, the faculty's average number of courses taught on environmental aspects was 0.48 .

A critical look at Table 10; Fig. 1 shows that a majority (96.24\%) of the male respondents were aware of the World Environment Day (June 05), followed by (92.48\%) World Earth Day (April 22), (90.98 \%) World Soil Day (December 05), (92.48 \%) World Forest Day (March 21), (92.78 \%) World Water Day (March 22) and (81.20 \%) International Day for Natural Disaster Reduction (October 13). In the case of the female respondents, cent $\%$ of the respondents was aware of World Environment Day (June 05) and World Earth Day (April 22), respectively, followed by World Soil Day (December 05) (95.45\%), World Forest Day (March 21) (88.64 \%), World Water Day (March 22) (93.18 \%), International Day for Natural Disaster Reduction (October 13) (81.82\%). At the overall level, a majority $(97.18 \%)$ of the respondents were aware of World Environment Day (June 05), followed by World Earth Day (April 22) (94.35 \%), World Soil Day (December 05) (92.09 \%), World Forest Day (March 21) (91.53 \%), World Water Day (March 22) (92.66 \%) and International Day For Natural Disaster Reduction (October 13) (81.36\%).

The data presented in Table 11 show that $45.12 \%$ of the male respondents had medium awareness about environment-related days, followed by 42.10 and $12.78 \%$ of the respondents with high and low awareness about environment-related days, respectively. However, more than half $(56.83 \%)$ of the female respondents had medium awareness about environment-related days, followed by 31.81 and $11.36 \%$ of respondents who had high and low awareness about environment-related days, respectively. At the

Table 9 Distribution of the respondents according to courses taught on environmental aspects (faculty)

\begin{tabular}{lllll}
\hline S1. No. & Category & \multicolumn{2}{l}{ Respondents } & \\
\cline { 3 - 5 } & & $\begin{array}{l}\text { Male } \\
(N=65)\end{array}$ & $\begin{array}{l}\text { Female } \\
(N=15)\end{array}$ & $\begin{array}{l}\text { Overall } \\
(N=80)\end{array}$ \\
\hline 1. & Taught & $22(33.85)$ & $05(33.33)$ & $27(33.75)$ \\
2. & Not taught & $43(66.15)$ & $10(66.67)$ & $53(66.25)$ \\
& Total & $65(100.00)$ & $15(100.00)$ & $80(100.00)$ \\
& Average & 0.48 & 0.48 & 0.48 \\
\hline
\end{tabular}




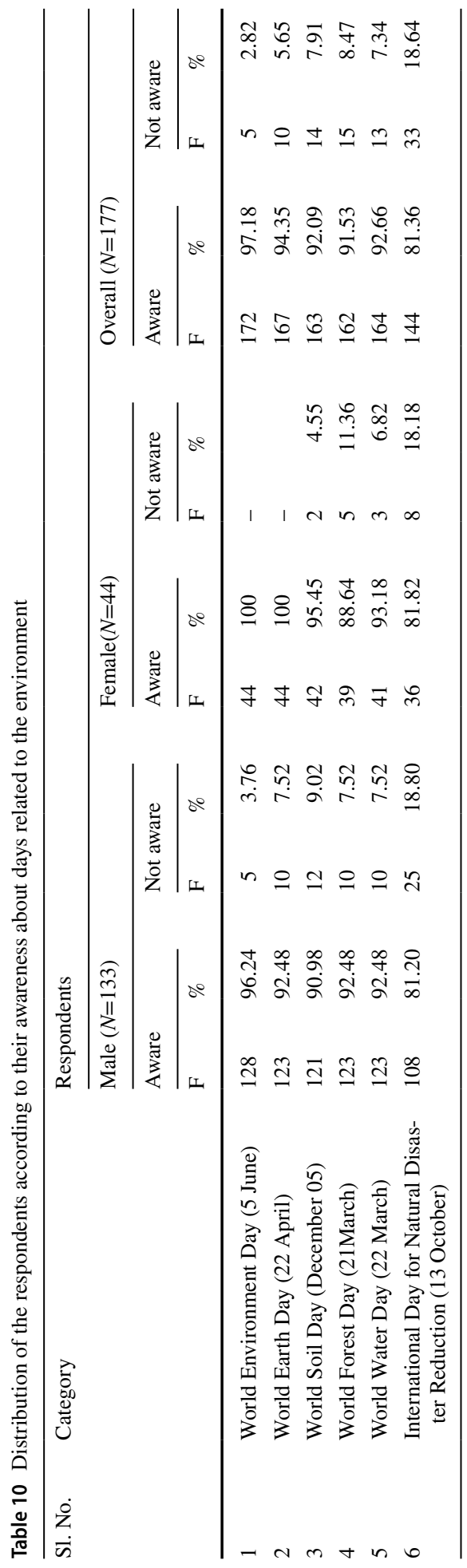




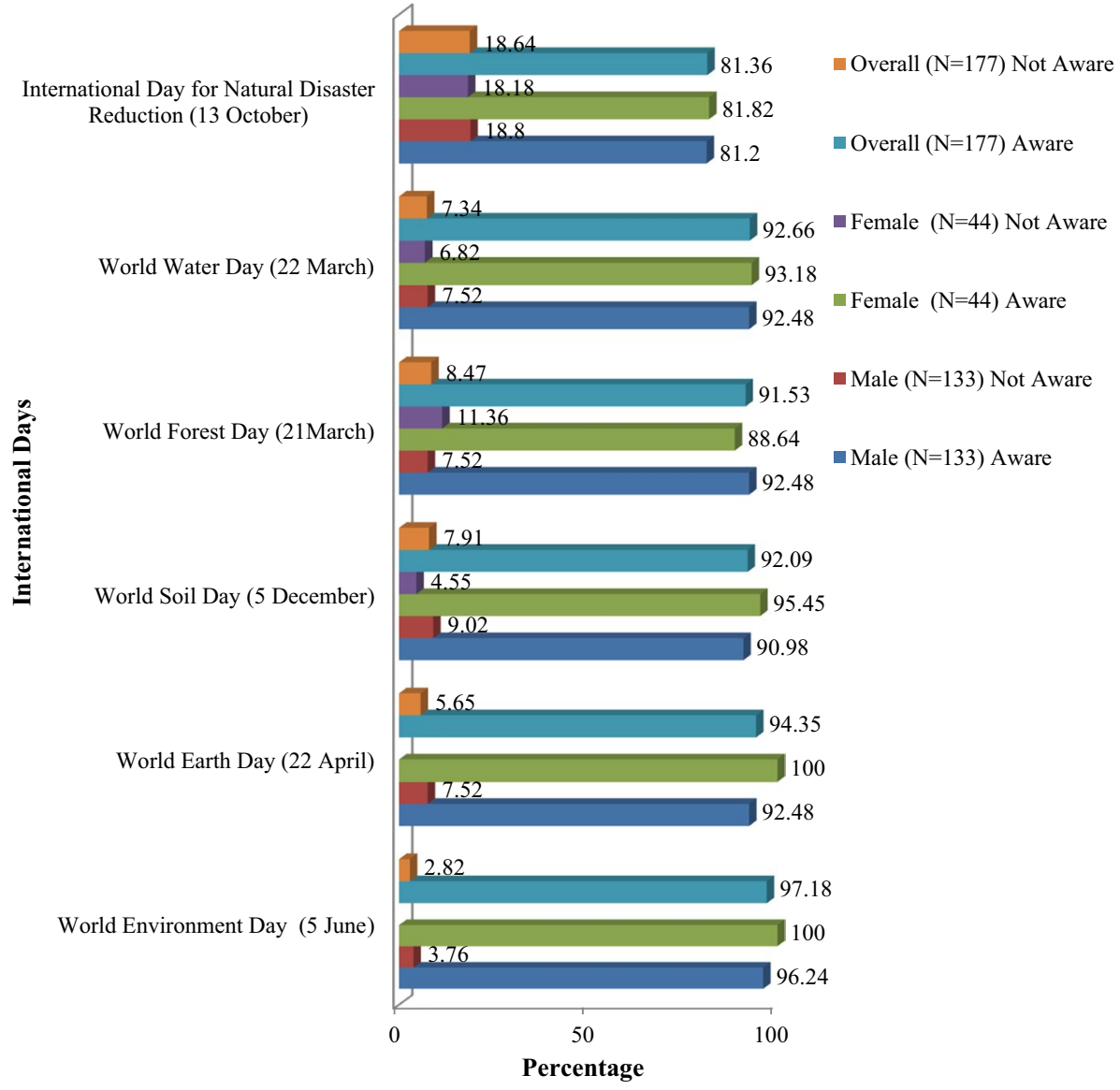

Fig. 1 Distribution of the respondents according to their awareness about environmental elated days

Table 11 Overall awareness about days-related environment

\begin{tabular}{lllll}
\hline S1. No. & Category (Score) & \multicolumn{2}{l}{ Respondents } & \\
\cline { 3 - 5 } & & Male $(N=133)$ & $\begin{array}{l}\text { Female } \\
(N=44)\end{array}$ & Overall $(s=177)$ \\
\hline 1. & Low (up to 4.34) & $17(12.78)$ & $05(11.36)$ & $22(12.43)$ \\
2. & Medium (4.35 to 6.63) & $60(45.12)$ & $25(56.83)$ & $80(45.20)$ \\
3. & High (6.64 and above) & $56(42.10)$ & $14(31.81)$ & $75(42.37)$ \\
& Total & $133(100.00)$ & $44(100.00)$ & $177(100.00)$ \\
& Average & 5.46 & 5.59 & 5.49 \\
\hline
\end{tabular}

overall level, less than half $(45.20 \%)$ of the respondents had medium awareness of environment-related days, followed by 42.37 and $12.43 \%$ of the respondents with high and low awareness of environmental-related days, respectively. The average awareness about 
environment-related of the male and female respondents was 5.46 and 5.59, respectively. At the overall level, the average awareness of the respondents was 5.49.

It is evident from the data in Table 12; Fig. 2 that an overwhelming percentage ( 96.24 $\%$ ) of the male respondents participated in tree plantation programmes, followed by cleanliness drives $(85.71 \%)$, environmental awareness programmes $(84.21 \%)$, village sanitation campaigns $(82.71 \%)$, lectures on environmental aspects $(79.70 \%)$, seminars on environmental aspects $(62.41 \%)$, workshops on environmental aspects $(54.14 \%)$ and trainings on environmental aspects $(52.63 \%)$. In contrast, a majority $(95.45 \%)$ of the female participants participated in tree plantation programmes, followed by cleanliness drives $(88.64 \%)$, environmental awareness programmes $(84.09 \%)$, village sanitation campaigns $(79.55 \%)$, lectures on environmental aspects $(59.09 \%)$, seminars on environmental aspects $(54.55 \%)$, trainings on environmental aspects $(38.64 \%)$, workshops on environmental aspects (31.82\%). At the overall level, $96.05 \%$ of the respondents participated in Tree Plantation programmes, followed by cleanliness drives (86.44\%), environmental awareness programmes $(84.18 \%)$, village sanitation campaigns (81.92 $\%)$, lectures on environmental aspects $(74.58 \%)$, seminars on environmental aspects $(60.45 \%)$, trainings on environmental aspects $(49.15 \%)$, workshops on environmental aspects $(48.59 \%)$.

Table 13 reveals that more than half $(52.63 \%)$ of the male respondents were under the medium category of participation in environmental-related activities, followed by 36.09 and $11.28 \%$ of the respondents who were under the high and low category of participation in environmental-related activities, respectively. However, more than three-fifths $(65.91 \%)$ of the female respondents had medium category of participation in environmental-related activities, followed by $20.45 \%$ and $13.64 \%$ of respondents who had high and low categories of participation in environmental-related activities, respectively. At the overall level, more than half $(55.93 \%)$ of the respondents had medium category of participation in environmental-related activities, followed by 32.20 and $11.86 \%$ respondents who had the high and low category of participation in environmental-related activities, respectively. The average participation in environmental-related activities by the male and female respondents was 5.98 and 5.27, respectively. At the overall level, the average participation in environmental-related activities by the respondents was 5.80 .

A critical look at Table 14; Fig. 3 indicates the kitchen waste management: a majority $(79.70 \%)$ of the male respondents were using garbage bins always, followed by use of municipality garbage bin $(67.67 \%)$, manure pit $(66.17 \%)$, use of one common garbage bin for all household waste $(60.15 \%)$. However, $22.92 \%$ of the respondents sometimes used manure pits, followed by garbage bins (17.36\%). A considerable percentage of the respondents $(65.28 \%)$ had never thrown waste on the roadside, followed by the use of one common garbage bin for all household waste $(26.39 \%)$. An overwhelming percentage $(90.91 \%)$ of female respondents always used garbage bins for waste management. It was followed by use of municipality garbage bin $(63.64 \%)$, manure pit $(50.00 \%)$, use of one common garbage bin for all household waste $(38.64 \%)$, whereas $40.91 \%$ of the respondents sometimes used manure pit followed by use of one common garbage bin for all household waste $(22.73 \%)$, municipality garbage $(18.18 \%)$, more than four-fifths $(84.09 \%)$ of the respondents never threw garbage on the roadside, followed by use of one common dust bin for all household waste $(38.64 \%)$. At the overall level, more than four-fifths $(82.49 \%)$ of the respondents used garbage bins for waste management, followed by use of municipality garbage $(66.67 \%)$, manure pit $(62.15 \%)$, use of one common garbage bin for all household waste $(54.80 \%)$, whereas $28.81 \%$ of the respondents sometimes used manure pit followed by use of municipality garbage $(18.08 \%)$, and three-fourths $(74.01 \%)$ of the 


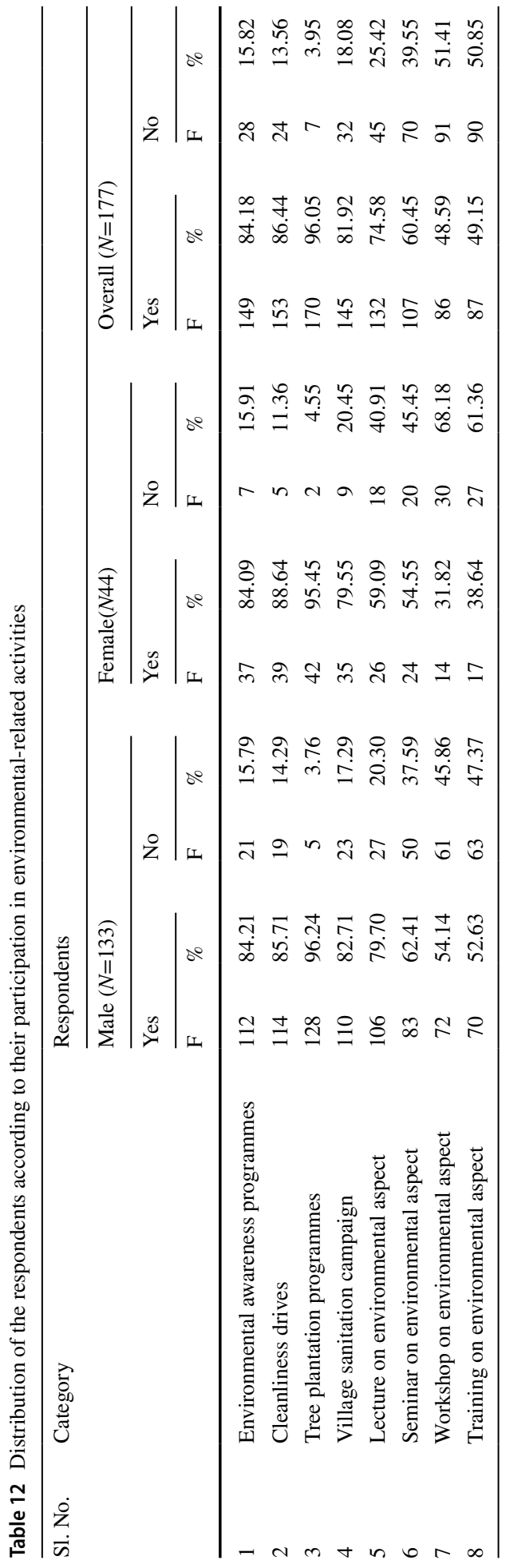






Fig. 2 Distribution of the respondents according to their participation in environmental-related activities

respondents never threw garbage on the roadside followed by use of one common garbage bin for all household waste (31.07\%).

As regards waste plastic material, more than half $(68.06 \%)$ of the male respondents always used dust bins, followed by respondents who separately collected and sold it (47.22\%), whereas $39.58 \%$ of the respondents had sometimes reused, and $21.53 \%$ of the respondents never collected separately and sold it. More than half, $68.18 \%$ of the female respondents always used garbage bins for plastic waste, followed by respondents who separately collected and sold it (59.09\%). More than half $(54.55 \%)$ of the 
Table 13 Overall participation in environmental-related activities

\begin{tabular}{lllll}
\hline S1. No. & Category (Score) & Respondents & \\
\cline { 3 - 5 } & & Male $(N=133)$ & $\begin{array}{l}\text { Female } \\
(N=44)\end{array}$ & Overall $(N=177)$ \\
\hline 1. & Low (up to 3.81) & $15(11.28)$ & $06(13.64)$ & $21(11.86)$ \\
2. & Medium (3.82 to 7.78) & $70(52.63)$ & $29(65.91)$ & $99(55.93)$ \\
3. & High (7.79 and above) & $48(36.09)$ & $09(20.45)$ & $57(32.20)$ \\
& Total & $133(100.00)$ & $44(100.00)$ & $177(100.00)$ \\
& Average & 5.98 & 5.27 & 5.80 \\
\hline
\end{tabular}

respondents sometimes reused, and an equal number (15.91\%) of the respondents never threw it in the garbage bin and respondents who collected separately and sold it, respectively. At the overall level, $72.32 \%$ of the respondents have always used garbage bins, followed by separate respondents who collected and sold it $(53.11 \%)$, less than half (45.76\%) of the respondents had sometimes reused and $21.47 \%$ of the respondents never separately collected and sold it.

In the case of glass waste material, more than half (59.03\%) of the male respondents always collected and threw it separately, followed by throwing it in the dust bin $(50.69 \%)$. In contrast, an equal number $(31.94 \%)$ of the respondents were sometimes separately collected and sold or reused, and $31.25 \%$ of the respondents never reused glass waste material. More than half $(68.18 \%)$ of the female respondents always collected and threw it separately. $50.00 \%$ of the respondents sometimes reused it, and $34.09 \%$ of the respondents never threw it in the dust bin. At the overall level, $64.97 \%$ of the respondents always collected and threw it separately, followed by respondents who threw it in the dust bin $(53.67$ $\%$ ), whereas $38.42 \%$ of the respondents sometimes reused it, and $32.20 \%$ of the respondents never threw it in the dust bin.

With regard to empty tins of pesticides/insecticides management, less than three-fourths $(73.61 \%)$ of the male respondents always disposed it off separately, followed by (38.89 $\%$ ) of respondents who collected and threw it in the common garbage bin; $19.44 \%$ sometimes collected and threw it in the common garbage bin, and $43.75 \%$ never threw it in the common garbage bin, whereas four-fifths of the female respondents always disposed of it separately followed by $15.91 \%$ sometimes collected and threw it outside in the common garbage bin. More than three-fifths $(61.36 \%)$ of the respondents never threw it in the common garbage bin. At the overall level, $81.92 \%$ of the respondents always disposed of it separately, followed by $19.77 \%$ of the respondents who sometimes collected and threw it outside in the common garbage bin. $50.85 \%$ of the respondents never threw it in the common garbage bin.

As far as management of carry bags of polythene is concerned, $52.08 \%$ of the male respondents always threw them in the common dust bin, followed by $26.39 \%$ of the respondents who sometimes collected and reused them. $46.53 \%$ of the respondents never burnt polythene carry bags. Similarly, $68.18 \%$ of the female respondents collected and reused the polythene carry bags, followed by $52.27 \%$ of the respondents who sometimes burnt them. $47.73 \%$ of the respondents never threw them in the common dust bin. At the overall level, $55.93 \%$ of the respondents collected the carry bags for reuse, followed by $29.38 \%$ of the respondents who sometimes burnt the polythene carry bags, and $35.59 \%$ of the respondents never threw the carry bags of polythene in the common dust bin. 


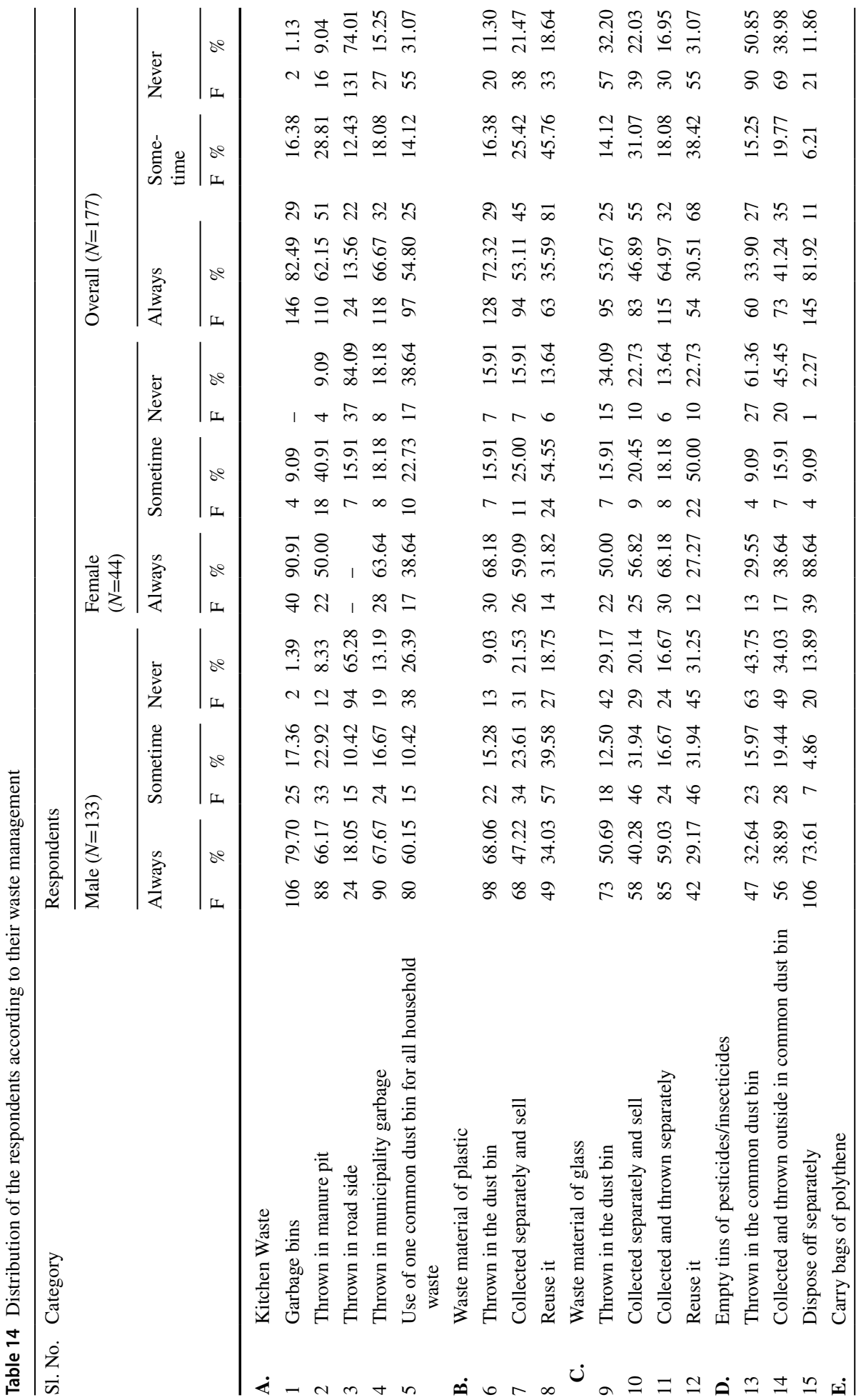




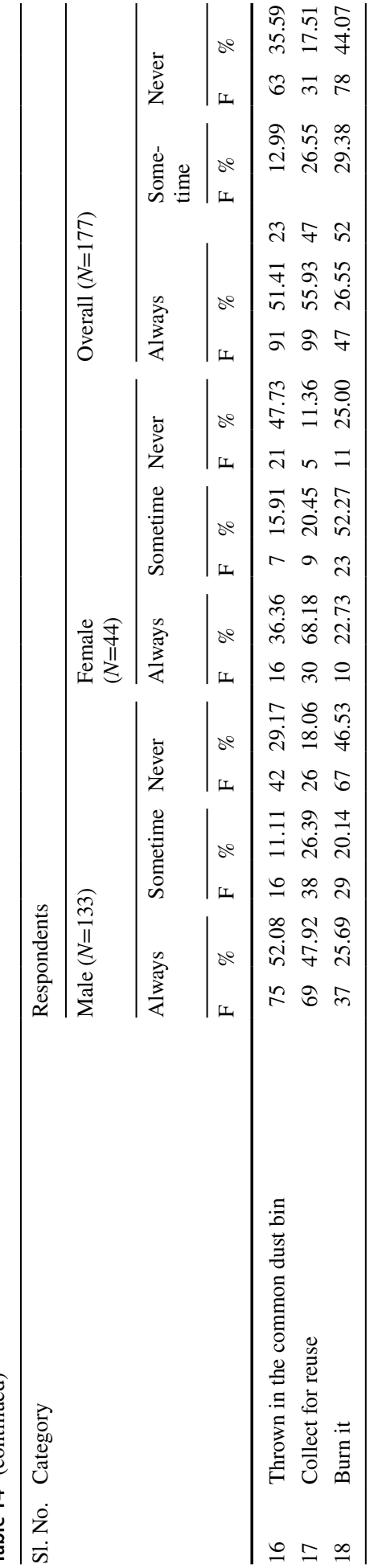




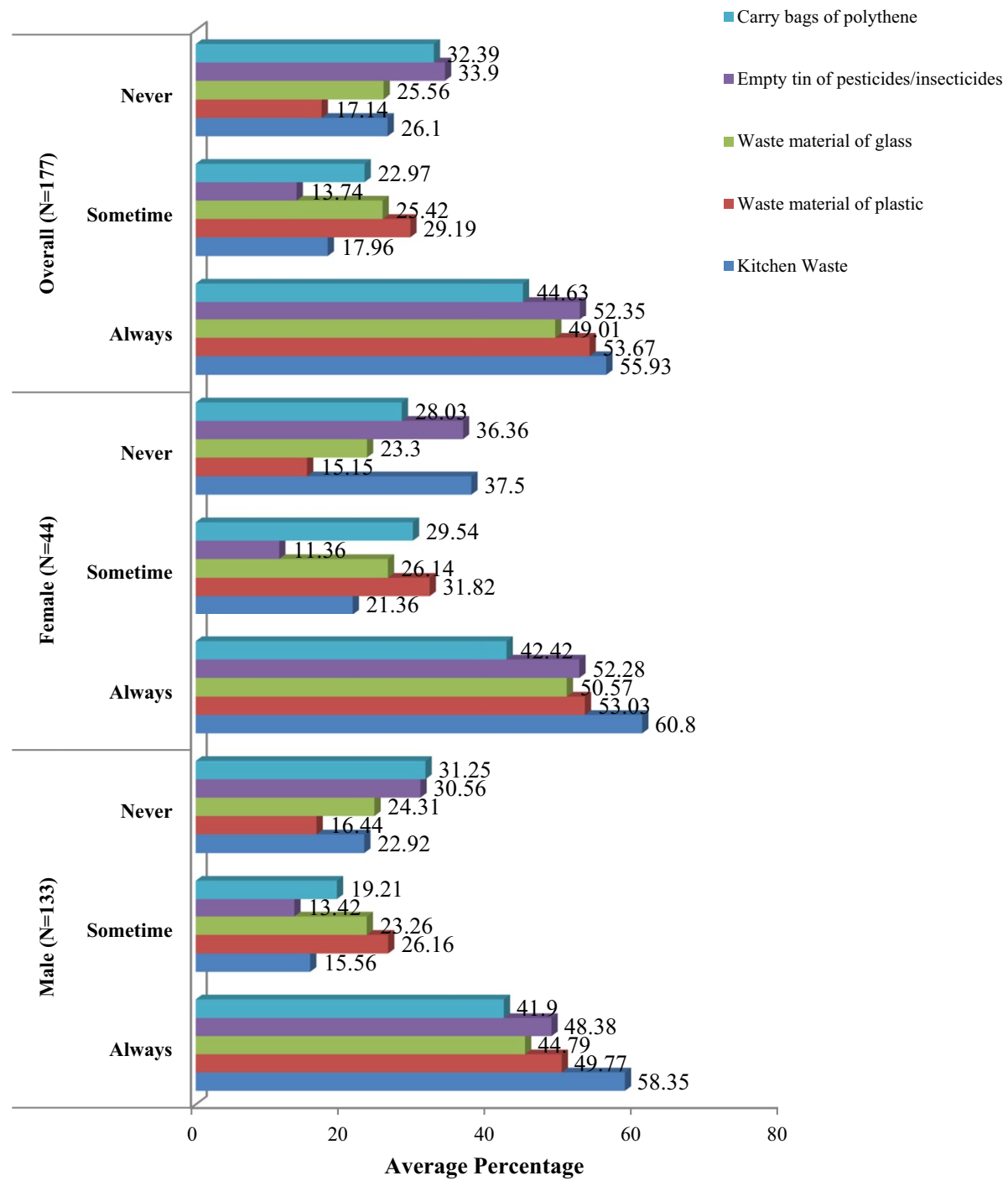

Fig. 3 Distribution of the respondents according to their component-wise management of wastes

Table 15 Overall waste management

\begin{tabular}{lllll}
\hline Sl. No. & Category (Score) & Respondents & \\
\cline { 3 - 5 } & & Male $(N=133)$ & $\begin{array}{l}\text { Female } \\
(N=44)\end{array}$ & Overall $(N=177)$ \\
\hline 1. & Low (up to 15.35) & $16(12.03)$ & $06(13.64)$ & $22(13.43)$ \\
2. & Medium (15.36 to 29.57) & $89(66.92)$ & $30(68.18)$ & $119(67.23)$ \\
3. & High (29.58 and above) & $28(21.05)$ & $08(18.18)$ & $36(20.34)$ \\
& Total & $133(100.00)$ & $44(100.00)$ & $177(100.00)$ \\
& Average & 22.67 & 21.89 & 22.47 \\
\hline
\end{tabular}


Table 15 shows that more than three-fifths $(66.92 \%)$ of the male respondents were of the medium category of the overall management of wastes, followed by 21.05 and 12.03 $\%$ of the respondents who were of the high and low category of overall waste management, respectively. Similarly, $68.18 \%$ of the female respondents were of the medium category of overall waste management, followed by $18.18 \%$ and $13.64 \%$ respondents who were of high and low category of overall waste management, respectively. Both males and females combined, more than three-fifths $(67.23 \%)$ of the respondents, were of the medium category of the overall waste management, followed by 20.34 and 13.43 $\%$ respondents who were of the high low category. The average management of wastes by male and female respondents was 22.67 and $21.89 \%$, respectively. At the overall level, the average waste management of the respondents was $22.47 \%$

Table 16; Fig. 4 show that more than three-fourths (76.69\%) of the male respondents always received environmental-related information through WhatsApp, followed by Television (74.43\%); YouTube $(67.67 \%)$; Websites $(65.41 \%)$ and $44.36 \%$ of the respondents sometimes received information through Radio, while $18.80 \%$ of the respondents never received information from Radio. Similarly, four-fifths $(84.09 \%)$ of the female respondents always got environmental-related information through WhatsApp, followed by Websites (70.45\%), Television (68.18\%), YouTube $(61.36 \%)$, and $56.82 \%$ of the respondents sometimes received information through Radio. An equal number (15.91 $\%$ ) of the respondents never got information through Radio and Facebook, respectively. At the overall level, $78.53 \%$ of the respondents always received environmental-related information through WhatsApp, Television (70.62 \%), Websites (66.67\%), YouTube $(66.10 \%)$, Facebook $(61.02 \%)$, whereas $47.46 \%$ of the respondents sometimes received information through Radio and $18.08 \%$ of the respondents never received information through Radio.

It is apparent from Table 17 that more than half (57.14\%) of the male respondents fall under the medium category of overall use of social media, followed by 27.07 and $15.79 \%$ of the respondents who were of high and low category of overall use of the social media, respectively. Similarly, $70.45 \%$ of the female respondents were of the medium category of overall use of social media, followed by 20.45 and $09.09 \%$ of respondents of high and low category of overall use of social media, respectively. At the overall level, more than threefifths $(60.45 \%)$ of the respondents were of the medium category of overall use of social media, followed by 25.42 and $14.12 \%$ of respondents who were of high and low category of overall use of social media. The average use of social media of the male and female respondents was 9.33 and $9.30 \%$, respectively. At the overall level, the combined average of the social media usage by both the respondents was $9.32 \%$. These findings are similar to the results of (Ammar et al. 2020).

From the data presented in Table 18, it can be seen that an overwhelming (93.98\%) of the male respondents had knowledge about the Wild Life Act, 1972 followed by the Environmental Protection Act, 1986 (92.48 \%), the Forest Act, 1980 (90.23\%), the Water (Prevention \& Control of Pollution) Act 1974 (87.22\%), the Air (Prevention \& Control of Pollution) Act1981 (86.47 \%), the Biodiversity Act, 2002 (84.21\%), the Motor Vehicle Act, $1988(81.20 \%)$. Similarly, $93.18 \%$ of the female respondents knew the Environmental Protection Act, 1986, followed by the Water (Prevention \& Control of Pollution) Act 1974 (90.91\%), the Air (Prevention \& Control of Pollution) Act, 1981 (88.64 \%), the Biodiversity Act, $2002(86.36 \%)$. At the overall level, $92.66 \%$ of the respondents knew the Environmental Protection Act, 1986 followed by the Wild Life Act, 1972 (92.09\%), the water (Prevention \& Control of Pollution) Act, 1974 (88.14 \%), the Air (Prevention \& Control of Pollution) Act, 1981 (87.01\%), and the Biodiversity Act, 2002 (84.75\%). 


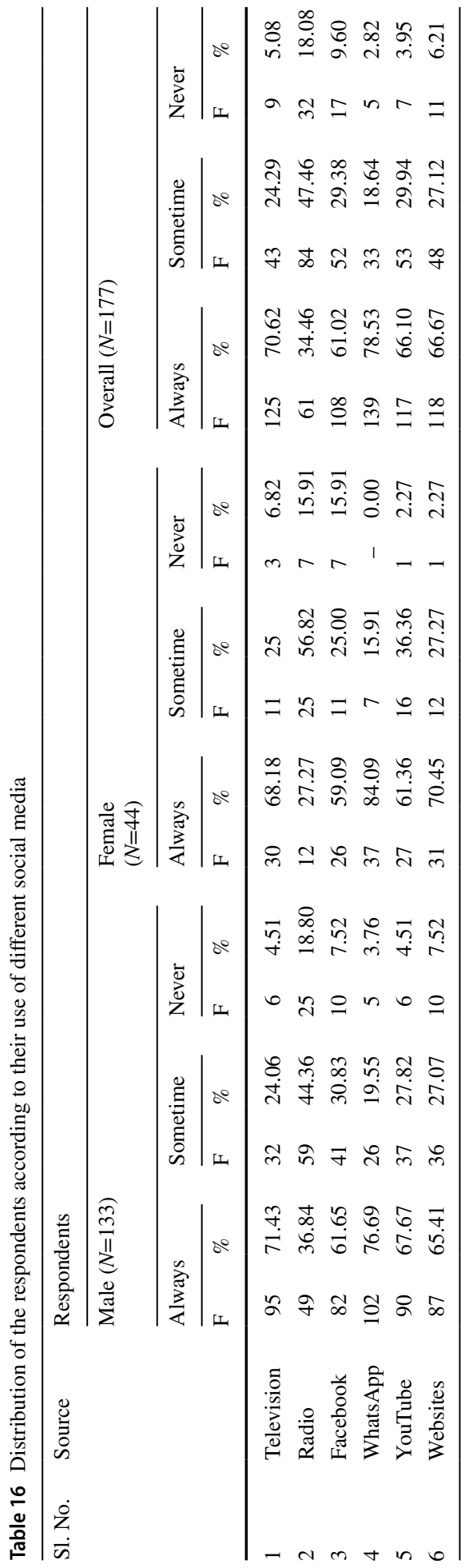




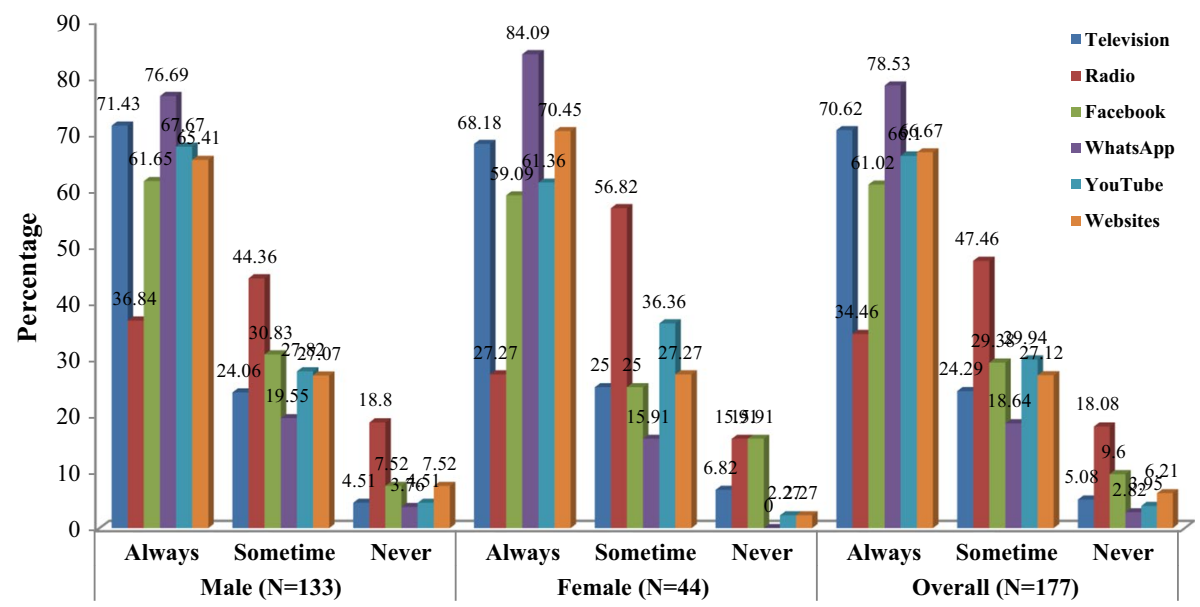

Fig. 4 Distribution of the respondents according to their use of different social media

Table 17 Overall use of social media

\begin{tabular}{lllll}
\hline S1. No. & Category (Score) & Respondents & \\
\cline { 3 - 5 } & & Male $(N=133)$ & $\begin{array}{l}\text { Female } \\
(N=44)\end{array}$ & Overall $(N=177)$ \\
\hline 1. & Low (up to 6.91) & $21(15.79)$ & $04(09.09)$ & $25(14.12)$ \\
2. & Medium ( 6.92 to 11.72) & $76(57.14)$ & $31(70.45)$ & $107(60.45)$ \\
3. & High ( 11.73 and above) & $36(27.07)$ & $09(20.45)$ & $45(25.42)$ \\
& Total & $133(100.00)$ & $44(100.00)$ & $177(100.00)$ \\
& Average & 9.33 & 9.30 & 9.32 \\
\hline
\end{tabular}

The data in Table 19 indicated that more than three-fourths $(77.44 \%)$ of the male respondents had high knowledge about the Acts related to environmental protection, followed by 18.80 and $3.76 \%$ of the respondents who had medium less knowledge about the Acts pertaining to environmental protection, respectively. Similarly, $75.00 \%$ of the female respondents had high knowledge about the Acts related to environmental protection, followed by 22.73 and $2.44 \%$ respondents who had medium and less knowledge about the Acts pertaining to environmental protection, respectively. At the overall level, more than half $(52.54 \%)$ of the respondents had high knowledge about the Acts related to environmental protection, followed by 33.90 and $13.56 \%$ respondents who had medium and less knowledge about the Acts pertaining to environmental protection, respectively. The average knowledge about the Acts related to environmental protection of the male and female respondents was 9.33 and 9.30, respectively. At the overall level, the average use of social media of the respondents was 9.32 .

A critical look into Table 20 showed $(79.70 \%)$ of the male respondents equal, high and strong agreement with the statement 'I feel green zone surrounding to the home which improve air quality' and 'Excess use chemical pesticides cause hazardous effects to the 





Table 19 Overall knowledge about Acts related to environmental protection

\begin{tabular}{lllll}
\hline Sl. No. & Category (Score) & \multicolumn{2}{l}{ Respondents } & \\
\cline { 3 - 5 } & & Male $(N=133)$ & $\begin{array}{l}\text { Female } \\
(N=44)\end{array}$ & Overall $(N=177)$ \\
\hline 1. & Less (up to 4.49) & $05(3.76)$ & $01(2.44)$ & $24(13.56)$ \\
2. & Medium ( 4.50 to 7.72) & $25(18.80)$ & $10(22.73)$ & $60(33.90)$ \\
3. & High ( 7.73 and above) & $103(77.44)$ & $33(75.00)$ & $93(52.54)$ \\
& Total & $133(100.00)$ & $44(100.00)$ & $177(100.00)$ \\
& Average & 9.33 & 9.30 & 9.32 \\
\hline
\end{tabular}

environment' followed by 'green manuring is an effective source to promote eco-friendly environment for agricultural development' (78.55\%); 'I think community efforts will be helpful for the environmental protection' (78.20\%); ' I believe that organic fertilizers are helpful for sustaining environmental balance' (77.44\%); ' I feel use of solar based equipment to minimize pollution' (75.19\%); 'I feel organic food to minimize risk of environmental damage' (74.44\%); 'I think recyclable things are minimize environment damages' (71.43 \%); and 'I feel biodegradable goods are useful to the environment' (70.68 \%), whereas an equal number ( $36.09 \%$ ) of the male respondents agreed to the statement that 'legal measures are better option to protect environmental damages' and 'I avoid long ride of motorcycle to minimize air pollution', respectively, followed by 'I am worried wherever read about of worldwide environmental tragedies' (33.83 \%); 'I think washing of clothes, animal and machinery in natural water bodies cause harmful effects to the environment' (27.82 \%); the respondents undecided with the statement 'I think it is not my responsibility to protect environment' (15.79); the respondents who disagreed with 'I think it is meaningless to buy paper bags instead of nylon bags given for free in the market' (7.52\%); less than half (49.62\%) of the respondents Strongly Disagreed with the statement'. Similarly, by comparison, more than four-fifths $(88.64 \%)$ of the female respondents had high agreement with the statement 'green manuring is an effective source to promote an eco-friendly environment for agricultural development' followed by 'I feel use of solar-based equipment to minimize pollution' (79.55\%); 'I think community efforts will be helpful for the environmental protection' and 'I feel organic food to minimize the risk of environmental damage' (77.27 \%); 'I feel biodegradable goods are useful to the environment' and 'I feel green zone surrounding to the home which improves air quality' (75.00\%). More than half $(52.27 \%)$ of the respondents agreed with 'legal measures are a better option to protect environmental damages' and (11.76\%) of the respondents remained undecided about the statement 'I think it is not my responsibility to protect the environment', while $(2.27 \%)$ of the respondents strongly disagreed with all the seventeen statements. In this context, when referred to Table 21 , at the overall level, $(81.36 \%)$ of the respondents agreed with statements like 'Green manuring is an effective source to promote an eco-friendly environment for agricultural development' followed by 'I feel green zone surrounding to the home which improves air quality' (78.53\%); 'I think community efforts will be helpful for the environmental protection' (770.91 \%); 'I feel use of solar-based equipment to minimize pollution' (76.27\%); 'I feel organic food to minimize the risk of environmental damage' (75.14\%). Similarly, $40.11 \%$ of the respondents agreed with the statement 'legal measures are a better option to protect environmental damages' while $14.69 \%$ of the respondents were undecided about the statement 'I think it is not my responsibility to protect the environment'. $5.08 \%$ of the 


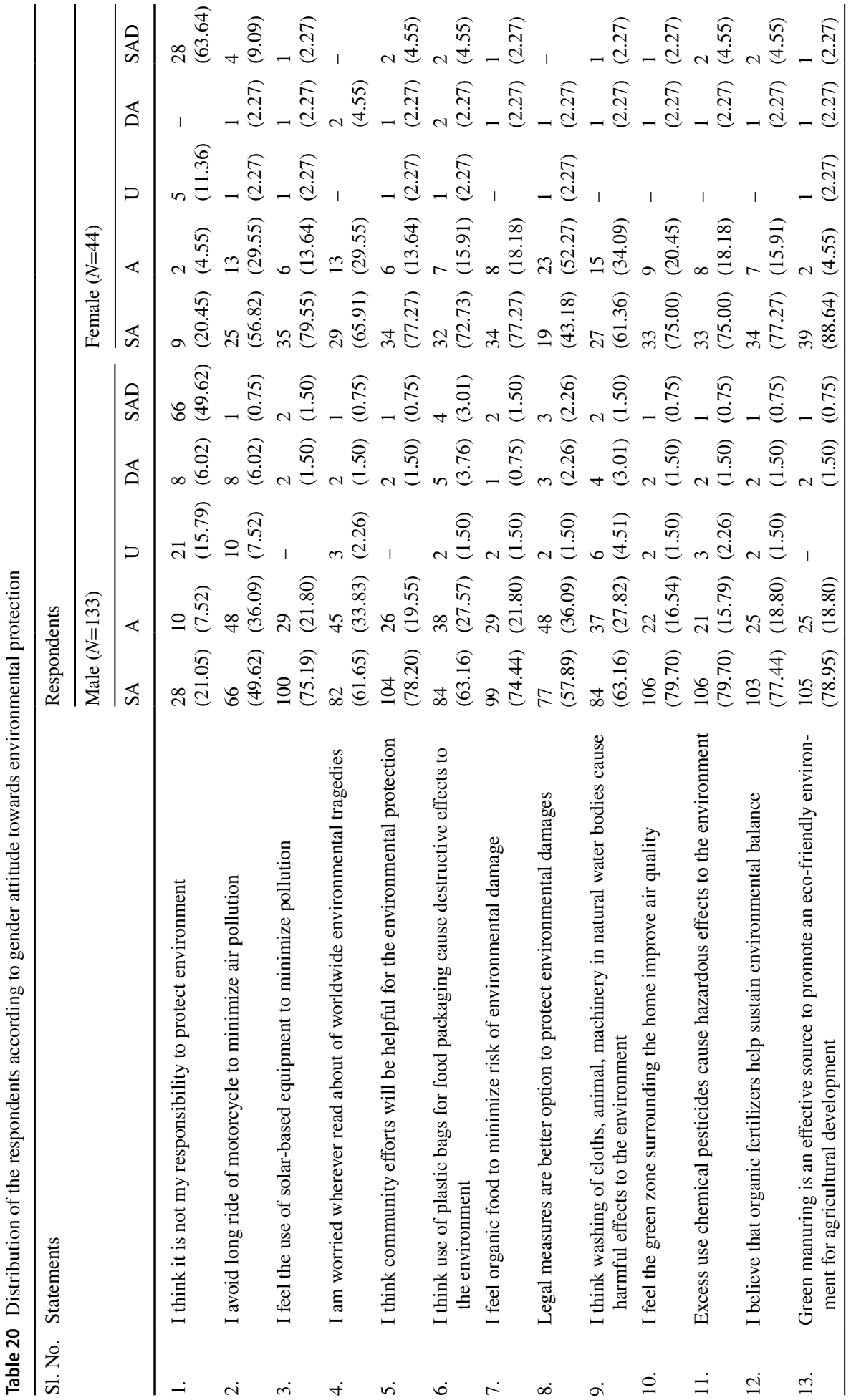




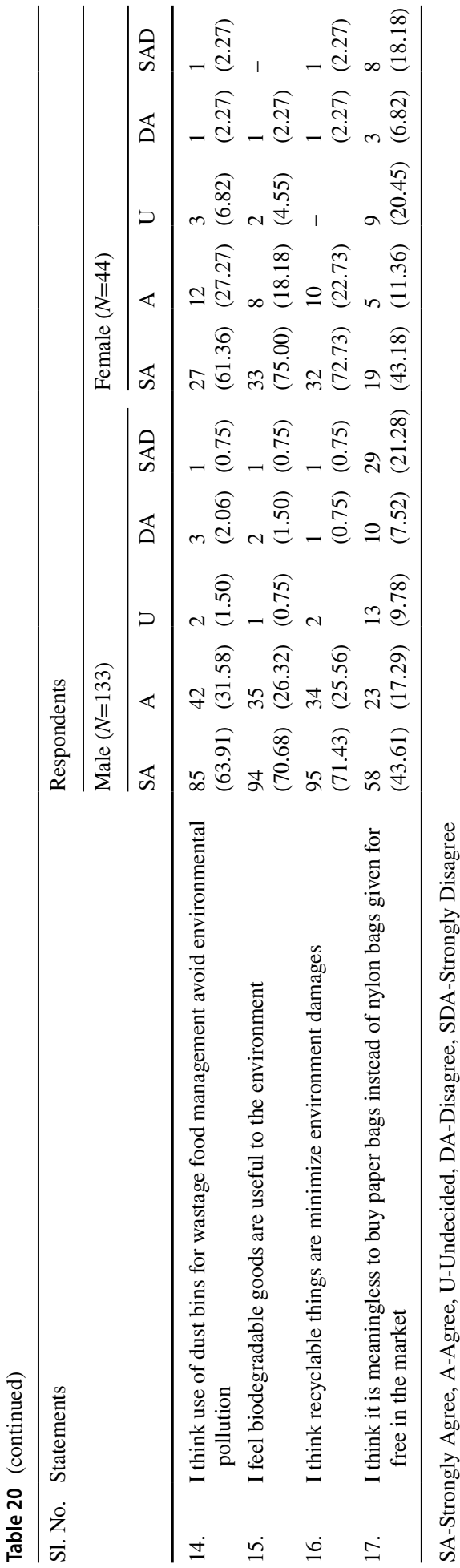




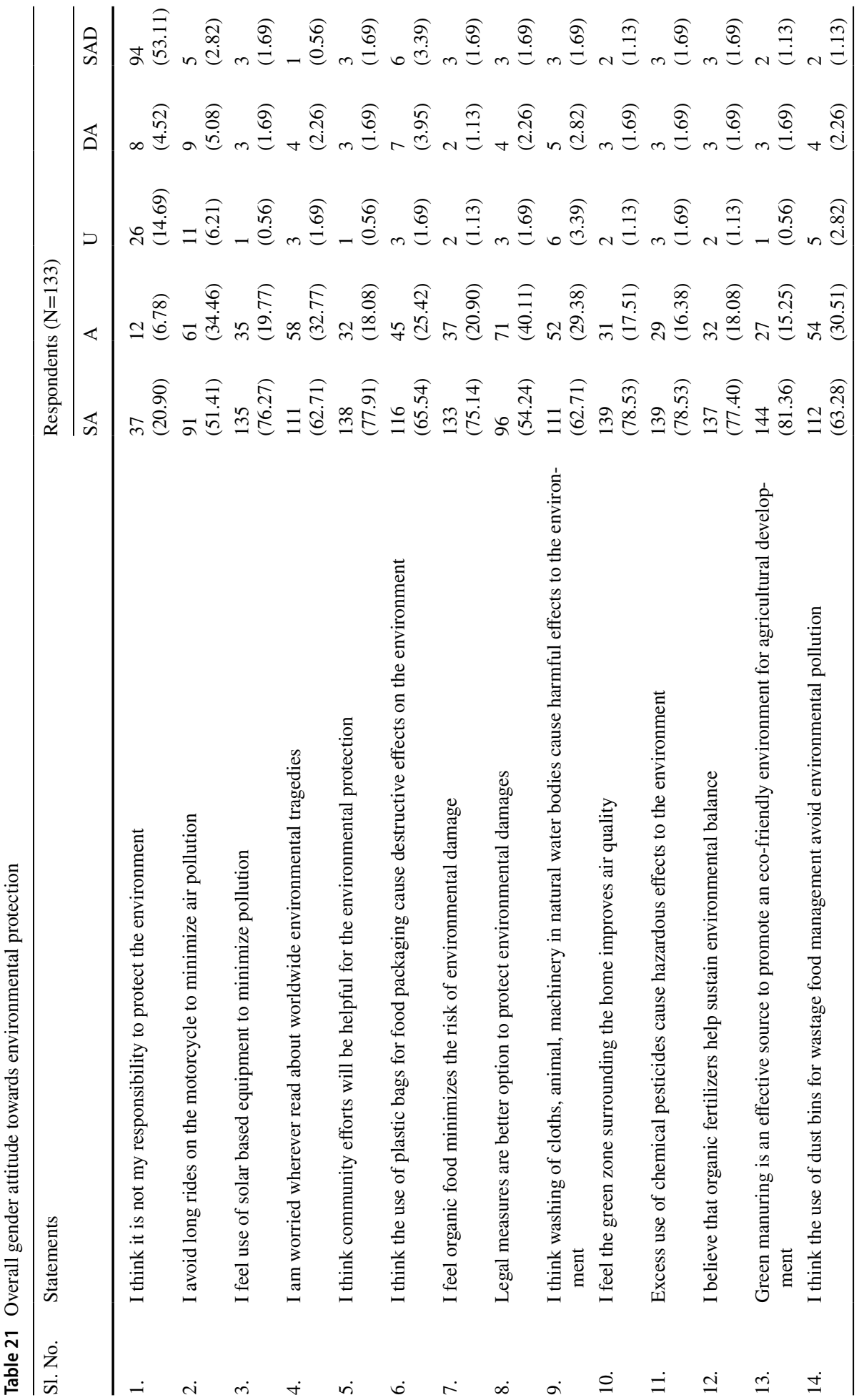






Springer 
Table 22 Overall gender attitude towards environmental protection

\begin{tabular}{lllll}
\hline S1. No. & Category & $\begin{array}{l}\text { Male } \\
(N=133)\end{array}$ & $\begin{array}{l}\text { Female } \\
(N=44)\end{array}$ & $\begin{array}{l}\text { Overall } \\
(N=177)\end{array}$ \\
\hline 1 & Very low & $6(4.51)$ & $4(9.09)$ & $10(5.65)$ \\
2 & Low & $16(12.03)$ & $3(6.82)$ & $19(10.73)$ \\
3 & Medium & $70(52.63)$ & $23(52.27)$ & $93(52.54)$ \\
4 & High & $27(20.30)$ & $10(22.73)$ & $37(20.90)$ \\
5 & Very high & $14(10.53)$ & $4(9.09)$ & $18(10.17)$ \\
& Total & $133(100.00)$ & $44(100.00)$ & $177(100.00)$ \\
& Average & 75.02 & 73.93 & 74.75 \\
\hline
\end{tabular}

respondents disagreed with 'I avoid long ride of the motorcycle to minimize air pollution'. More than half $(53.11 \%)$ of the respondents strongly disagreed with the statement 'I think it is not my responsibility to protect the environment'.

The results presented in Table 22 showed that more than half $(52.63 \%)$ of the male respondents had a medium attitude towards environmental protection, while one-fifths $(20.30 \%)$ of the respondents had a high attitude towards environmental protection. Further, $12.03 \%$ of the respondents had a low attitude towards environmental protection. Besides, $10.53 \%$ of the respondents had a high attitude, and $4.51 \%$ of the respondents had very low attitude towards environmental protection. In comparison, $52.27 \%$ of the female respondents had a medium attitude towards environmental protection, while $22.73 \%$ of the respondents had a high attitude. An equal number of the respondents $(9.09 \%)$ belonged to the very low and very high attitude categories towards environmental protection, respectively. The percentage under the category of low attitude towards environmental protection was 6.82 . At the overall level, more than half $(52.54 \%)$ of the respondents belonged to the medium attitude towards environmental protection category, followed by $20.90 \%$ of the respondents who had high, and $10.73 \%$ of the respondents who had a low attitude towards environment protection. Apart from these, $10.17 \%$ and $5.65 \%$ of the female respondents had a very high and a very low attitude towards environmental protection categories, respectively. The average male and female respondents' attitudes towards environmental protection were 75.02 and $73.93 \%$, respectively. At the overall level, the average attitude towards environmental protection of the respondents was $74.75 \%$.

Table 23 shows the correlation coefficient between male attitude and the dependent variables. The conclusion was that the membership of environmental organizations/societies and management of wastes were significant at 0.01 levels with correlation coefficient values of (r) 0.2358 and 0.2263 , respectively. In contrast, education, training received, courses taught and use of social media were significant at 0.05 level with correlation coefficient values of (r) $0.1621,0.1368,-0.1348$ and 0.1422 , respectively. The remaining variables like profession, service experience, the place with the longest duration, awareness about environmental days, participation in environmental-related activities and knowledge about the Environment Acts were found to have no relationship with the male attitude. Regarding female attitude, the correlation between dependent variable found that variables like membership of environmental organizations/societies $(\mathrm{r}=0.3481)$ and waste management $(\mathrm{r}=0.3942)$ were significant at 0.01 level, whereas training received $(\mathrm{r}=-0.2518)$, courses taught $(r=0.2963)$, use of the social media $(r=-0.2794)$ were significant at 0.05 level. The remaining variables had a non-significant correlation with the female attitude. At the overall level, age $(r=0.2855)$, participation in environmental-related activities $(r=0.2571)$, management of wastes $(\mathrm{r}=0.1982)$ were significant at 0.01 level with gender attitude and 
Table 23 Correlation coefficient

\begin{tabular}{|c|c|c|c|c|}
\hline \multirow[t]{2}{*}{ S1. No. } & \multirow[t]{2}{*}{ Variables } & \multicolumn{3}{|l|}{ 'r' value } \\
\hline & & $\begin{array}{l}\text { Male } \\
(N=133)\end{array}$ & Female $(N=44)$ & $\begin{array}{l}\text { Overall } \\
(N=177)\end{array}$ \\
\hline 1. & Profession & $-0.0915 \mathrm{NS}$ & $-0.0081 \mathrm{NS}$ & $-0.0600 \mathrm{NS}$ \\
\hline 2. & Education & $0.1621 *$ & $-0.1167 \mathrm{NS}$ & $0.0784 \mathrm{NS}$ \\
\hline 3. & Service experience & $0.0009 \mathrm{NS}$ & $0.0837 \mathrm{NS}$ & $0.0244 \mathrm{NS}$ \\
\hline 4. & Age & 0.0184 & $0.0281 \mathrm{NS}$ & $0.2852 * *$ \\
\hline 5. & Training received & $0.1368 *$ & $-0.2518^{*}$ & $-0.0002 \mathrm{NS}$ \\
\hline 6. & $\begin{array}{l}\text { Membership of Environmental Organization/Socie- } \\
\text { ties }\end{array}$ & $0.2358 * *$ & $0.3481 * *$ & $0.1350^{*}$ \\
\hline 7. & Place with longest duration & $0.0788 \mathrm{NS}$ & $-0.1810 \mathrm{NS}$ & $-0.0480 \mathrm{NS}$ \\
\hline 8. & Course taught & $-0.1348^{*}$ & $0.2963 *$ & $-0.1457 *$ \\
\hline 9. & Awareness about environmental days & $0.0289 \mathrm{NS}$ & $-0.0511 \mathrm{NS}$ & $0.0071 \mathrm{NS}$ \\
\hline 10. & Participation in environmental-related activities & $0.0545 \mathrm{NS}$ & $0.0419 \mathrm{NS}$ & $0.2571 * *$ \\
\hline 11. & Waste management & $0.2263 * *$ & $0.3942 * *$ & $0.1982 * *$ \\
\hline 12. & Use of social media & $0.1422 *$ & $-0.2794 *$ & $-0.1572 *$ \\
\hline 13. & Knowledge about environment acts & $0.0353 \mathrm{NS}$ & $-0.0690 \mathrm{NS}$ & $0.0284 \mathrm{NS}$ \\
\hline
\end{tabular}

$*$ = Significance at 0.05 level $* *=$ Significance at 0.01 level

membership in environmental organization/societies $(\mathrm{r}=0.1350)$ and use of the social media $(r=-0.1572)$ were significant at 0.05 level. The remaining variables like profession, education, service experience, training received, the place with the longest duration, awareness about environmental days and knowledge about the Environment Acts were nonsignificant with the gender attitude.

\section{Discussion}

The primary aim of this study was to identify and understand the trainees' personal, psychological, communicational and sociocultural characteristics on 11 independent variables. The age of the trainees is the physical and mental development of an individual. Generally, the young trainees are more active, highly motivating, enthusiastic and mostly accept changes. The middle-aged trainees are reluctant to accept new ideas. The old-aged trainees resist changes and are slow to accept modernization. Such a hypothesis in this research implied that a majority of both male and female respondents belonged to the middle-age group (Lee et al., 2013). This meant that both males and females had well-equipped knowledge about environmental protection due to awareness programmes organized at the college. Formal, informal and non-formal education play an important role in the capacity development of individuals and is one of the most effective tools to produce desirable changes in the behaviour of humans in order to achieve environmental protection (Emilio Abad-Segura et al. 2019). Most of the male respondents were post-graduates. They had knowledge, abilities, skills, character and mental powers. They had ethical values and could discern the right and wrong about the environment. (P. Ataei et al.2018). Brain and cognitive development can increase knowledge in early childhood education (Nuthbrown, 
2006; Spodek, 1993; Wolfe \& Brandt, 1998). Experience helps develop maturity and the ability to face varied situations that ultimately improve individual and organizational growth. Both males and females had service from low to medium categories. Most of the respondents belong to the students' category. This is a promising finding from this study to enhance knowledge of these by encouraging more of middle-aged and young respondents in environmental protection at an early age, early years period which are the most significant developments occurred in a person's life and they are sensitive to adopt positive environmental attitudes (Mustard, 2000; Nuthbrown, 2006; Kağıtçıbaşı et al. 2001; Spodek, 1993; Wilson, 1996). The males received more training about environmental protection than the females, which was organized by different organizational and professional societies. Training programmes can reduce the gap between the actual performance and what is needed and improve knowledge, skill, attitude, values, beliefs and understanding (Bandura, 1977). The females are less aware of various training organization sources than the males (Badkobi and Hadipour 2001). The school was the most important source of environmental information for females, while males chose the internet (Kaur and Dang, 2015; Sahin and Erkal, 2010). The females were fewer subscribers of membership of environmental organizations/societies than the males. Several organizations/societies have specific aims and objectives for environmental conservation. They organize several awareness programmes for the readers, and some organizations have their own publications like the newsletter, magazines and journals. Those who have taken membership have been receiving the publications as per the publication frequencies. It means the membership of environmental organizations/societies is beneficial to members to generate knowledge about environmental protection. Unlike the urban areas, the majority of the male and female respondents live in rural areas. Residential background plays an important role in the growth and development of an individual attitude towards environmental protection. Little Flower (2006) showed that students belonging to the rural background are comparatively better in terms of their environmental attitude and awareness than the students belonging to the urban background (Raju, 2007; Sundra, 2005). Educational institutions can incorporate environment-related courses in the course curricula (Nagra, 2010). Students are the course's target beneficiaries that can support developing positive feelings towards environmental protection (Mackey, 2012; Thapa, 1999) and encouraging their family members, neighbours and relatives to take care of the environment (Ballantyne, 2010). In the context of faculty who have taught courses and acquired more knowledge before teaching the students about the environmental courses, they search for innovative and new ideas. Every year, at global and national levels, environment-related days are celebrated on different themes and slogans related to environmental protection for encouraging the students and people and to take care of environmental protection, which makes their nearby surroundings safe and clean to enjoy a safer, cleaner and more prosperous future (Anonymous, 2018). Male and female respondents had medium awareness about environment-related days. The concerned organizations' responsibility is to celebrate environmental protection Days every year to create mass awareness about the importance of the environment in the ecosystem. Environmental protection is the responsibility of both males and females. It can prevent and protect harmful impacts on environmental damage. Nowadays, environmental protection awareness information through campaigns and activities organized by the different government and private organizations has a good impact on influencing the human attitude (Gender Tool Box, 2016). The gender equality approach is currently needed to pay attention to the equal participation of women and men in various environmental management activities. In the present investigation, females have less participation in environmental management-related activities, and both were found medium participation in environmental-related activities 
(Luna et al., 2015; Sivamoorthy et al., 2013). Waste management has become one of the key environmental concerns from the past decades, facing numerous global challenges. Vast quantities of municipal and industrial wastes are produced daily worldwide as a consequence of human activities. Solid waste increasing the environmental risk (Jerry, 2015) by the waste products, including human health risks, ecosystem degradation, contamination of soils and water, becomes more serious (United Nations Environmental Programme, 2011). This effect can be minimized by properly implementing waste management practices, including separating recyclable materials from non-recyclable waste (Ayodeji, 2010; Leton and Omotosho, 2004). In this research, most males and females were always taking care of the recyclable and non-recyclable wastes during the management of waste like kitchen, plastic, glass, pesticides/insecticides and bags of polythene waste (Ifegbesan 2008). Rapid access to information on social media has been increasing exponentially over recent years (Frazier, Culley, Hein, Williams and Tavakoli, 2014; Rauniar et al., 2014). Nowadays, the government and the concerned organizations for rapid dissemination of information and instant messaging are using social media like Television, Radio, Facebook, WhatsApp, YouTube and their websites (Eliana Andréa Severo et al. 2019; Dobson 1997; McQuail 1994) in images, videos or texts message (Kaplan \& Haenlein, 2010; Kietzmann, Hermkens, McCarthy, \& Silvestre, 2011). Through these, people can obtain information instantly and act accordingly. These are the good platforms for rapidly changing knowledge, behaviour and attitudes of the people in mass quantities in a particular phenomenon. Many concerned organizations are sending their information to the public via a social media platform regarding environmental protection. Due to the availability of time and economic conditions of the people, social media accessibility has increased or decreased. Most of the males have the habit of watching the news every day. They keep abreast with the happenings and gather up to date information and maintain their status in the surroundings. To achieve this, they are proactive on social media. Considering this, compared to females, most of the male respondents were always using social media platforms like WhatsApp followed by Television, YouTube, Facebook and Radio to obtain information (Cara et al., 2018) regarding environmental issues. Gender attitude towards environmental protection has been the focus of many studies in which it is accepted as a determining factor in human behaviour. Human behaviour towards environmental protection is shaped by an inclusive perception of the interaction between men and the environment. The interaction between and men and the environment is evaluated in two ways, i.e. human-centred perspectives environment as a immense resource for the living things and environment-centred context it does not agree and takes the environment as an entity of its own (Gulcin et al., 2017; Des Jardins 2012). In the current investigation, the positive attitude of the male and females towards environmental protection was representative of a human-centred context (Gulcin et al., 2017). The majority of the male respondents understood, more than the female respondents, that the excess use of chemical pesticides is hazardous to the environment and green zone surrounding the home, which improves air quality. Female respondents have a more favourable attitude than males to green manuring as an effective source to promote an eco-friendly environment for agricultural development and organic food to minimize environmental damage. We found that most of the male and female respondents' attitudes were moderate towards environmental protection. Attitude and risk perception of the gender were observed to differ in the male and female category depending upon their education, experience and awareness about environmental protection activities. Compared to the male and female, males have greater exposure to environmental issues while working in office work and house. They have also developed favourable, more positive attitudes towards environmental protection. Determining the level of attitudes of 
males and females towards environment protection is medium. So, taking necessary measures in line with results to improve the attitude levels through organizing awareness programs, activities, upgrading and revising course curriculum is of great importance in eliminating and preventing environmental problems. This study shows that environmental education is a never-ending and lifelong process that cannot be limited to educational institutions and various organizations. NGOs, grassroots organizations and social media are all significant functions in providing information and increasing environmental protection awareness. All the educational institutes, state and private organizations should organize and coordinate activities to develop a positive attitude towards environmental protection. In turn, it will be helpful to make the environment pollution free and keep human beings healthier and prosperous.

\section{Conclusions}

This research recognized the results of gender attitude towards environmental protection. Firstly, the study collected data from the participants who have attended the training programmes on environmental protection through structured online questions. This investigation produced useful information for developing an effective environmental protection plan. The results concluded that gender attitudes are significant because they affect environmental issues, environmental protection and people. Everyone, including students and faculties, has the responsibility to protect the environment. The majority of the males and females felt that green manuring is a valuable source to promote an eco-friendly environment for agricultural development and green zone surrounding due to air environment experiencing both male and females the improvement during the pandemic outbreak. During the lockdown period, people had more free time to participate in home cleanliness and social media, which increased their desire to be present online. As a result, gender attitudes changed towards environmental protection, and the protected environment would pave the way for the prevention of pandemic diseases. Basic information on gender issues and specific environmental protection measures can be obtained from social media. In this study, female respondents were more conscious about environmental protection than male respondents. There is an urgent need for qualitative studies to recognize the underlying reasons for this evaluation. The Environmental Protection Authorities and the Government should pay more attention to attitudinal changes towards environmental protection. The study also found that there is an overall impression of moderate attitude of gender towards environmental protection. There is a need to organize social activities, panel discussions, conferences and seminars for the benefit of both male and female participants to encourage high and positive gender attitudes towards environmental concern.

Author contribution statement All the authors of this paper are equally involved in conducting the research and preparation of this research paper.

\section{Declarations}

Conflict of interest All the authors declare that they have no conflict of interest.

Ethical approval This article does not contain any studies with human participants or animals performed by any of the authors. 


\section{References}

Akıllı, M., \& Yurtcan, T. (2009). An investigation of prospective science teachers attitudes towards in terms of different factors (Sample of Kazım Karabekir Education Faculty). Erzincan University Journal of Education Faculty, 11(2), 119-131

Aksel, Sundströma, \& Aaron, M. (2014). McCright Gender differences in environmental concern among Swedish citizens and politicians. Environmental Politics, 23 (6): 1082-1095, https://doi.org/10.1080/ 09644016.2014.921462

Alexander, S. E. (2000). Resident attitudes towards conservation and the Black Howler Monkeys in Belize: the community baboon sanctuary. Environmental Conservation, 27(4), 341-350

Allen, J. B., \& Ferrand, J. L. (1999). Environmental locus of control, sympathy, and pro-environmental behaviour: A test of Geller's actively caring hypothesis. Environment and Behavior, 31, 338-353

Allendorf, T. D., Smith, J. L. D., \& Anderson, D. H. (2007). Residents' perceptions of RoyalBardia National Park, Nepal. Landscape and Urban Planning, 82(1), 33-40

Allport, E. H. (1924). Social psychology. Boston: Houghton MifflinPp. xiv +453.

An, L., Lupi, F., Liu, J., Linderman, M. A., \& Huang, J. (2002). Modelling the choice to switch from fuelwood to electricity Implications for giant panda habitat conservation. Ecological Economics, 42(3), $445-457$

Ana Isabel Gil-Lacruz, Marcuello, C., \& Isabel Saz-Gil, M. (2019). Gender differences in European volunteer rates. Journal of Gender Studies, 28(2), 127-144. DOI: https://doi.org/10.1080/09589236.2018. 1441016

Andrej, S., Natalija Spur, \& Sonja, S. (2016). Public attitudes and opinions as dimensions of efficient management with extensive meadows in Natura area, Journal of Environmental Management, 183:637-46

Andrej, F., \& Andrej, B. (2019). Public attitudes toward environmental protection in the most developed countries: The Environmental Concern Kuznets Curve theory. Journal of Environmental Management, 231, 968-981

Annepu, R. K. (2012). Sustainable solid waste management in India. Accessed 29 Dec 2016. https://www. seas.columbia.edu/earth/wtert/sofos/SustainableSolidWasteManagementinIndia_Final.pdf.

Anonymous (2018). Environment day special, J\&K Envis Newsletter State of Environment \& its Related Issues in J\&K, 5(2), June 2018

Arcury, T. A., Scollay, S. J., \& Johnson, T. P. (1987). Sex differences in environmental concern and knowledge. Sex Roles, 16, 463-472

Ary D., Jacobs, L. C., Irvine, C. K. S., \& Walker, D. (1984). Introduction to research in education: Holt, Rinehart and Winston, Inc.

Atasoy, E. (2005). Çevre Đcin Egitim: Đlkögretim Ögrencilerinin Cevresel Tutum ve Cevre Bilgisi Üzerine Bir Calisma. Bursa: Yayimlanmamis Doktora Tezi. Uludağ Üniversitesi, Sosyal Bilimler Enstitüsü

Ayodeji, I. (2010). Exploring secondary school students' understanding and practices of waste management in Ogun State, Nigeria. International Journal of Environmental and Science Education, 5(2), 201-215

Badkobi, A., \& Hadipour, M. (2001). Assessment of primary school teachers' educational condition in different zones of Tehran Municipality in Environmental subjects and elevating their Awareness. Scientific Quarterly Journal Environment, 33, 79-80

Baker, S. (2016). Sustainable Development, Second Ed. London: Routledge

Baldwin, J. M. (1901-1905). Dictionary of philosophy and psychology. (3 vols.) New York: Macmillan. Pp. xxiv + 644; xvi + 892; xxvi + 542; viii -f- 543-1192

Ballantyne, R. D. J. (2010). Exploring the impact of integrated fieldwork, reflective and metacognitive experiences on student environmental 242 learning outcomes. Australian Journal of Environmental Education, 26, 47-64

Bandara, R., \& Tisdell, C. (2003). Comparison of rural and urban attitudes to the conservation of Asian elephants in Sri Lanka: empirical evidence. Biological Conservation, 110(3), 327-342

Barr, S., Gilg, A. W., \& Ford, N. J. (2001). A conceptual framework for understanding and analyzing attitudes towards household-waste management. Environment and Planning, 33(11), 2025-2048

Baykal, H., \& Baykal, T. (2008). Küresellesendünya'daçevresorunları.Mustafa Kemal Universitesi Sosya lBilimler Enstitüsü Dergisi,59): 17

Bell, L. C. (2001). Establishment of native ecosystems after mining-Australian experience across diverse biogeographic zones. Ecological Engineering, 17, 179-186

Berenguer, J., Corraliza, J. A., \& Martin, R. (2005). Rural-urban differences in environmental concern, attitudes, and actions. European Journal of Psychological Assessment, 21(2), 128-138

Berkes, F., Colding, J., \& Folke, C. (2000). Rediscovery of traditional ecological knowledge as adaptive management. Ecological Applications, 10(5), 1251-1262 
Bin, Z., Kee-hung, L., Bo, W., \& ZhaohuaWanga (2019). From intention to action: How do personal attitudes, facilities, accessibility and government stimulus matter for household waste sorting. Journal of Environmental Management, 233, 447-458

Blackwell, R. D., Miniard, P. W., \& Engel, J. F. (2006). Consumer behaviour. 10th edition, Thomson Learning, South-Western

Blankenau, J., Snowden, M., \& Langan, M. (2008). Understanding environmentalism in a red, agricultural state: The impact of political party identification and place of residence. Sociological Spectrum, 28(1), 55-80. https://doi.org/10.1080/02732170701675201

Blocker, T. J., \& Eckberg, D. L. (1997). Gender and environmentalism. Social Science Quarterly, 78, 841-858

Bogardus, E. S. (1931). Fundamentals of social psychology (2nd ed., p. 444). New York: Century. P

Bogner, F. X. (2000). Environmental perceptions of Italian and some European non-Mediterranean pupil populations. Fresenius Environmental Bulletin, 9, 570-581

Bonnett, M., \& Williams, J. (1998). Environmental Education and Primary Children's Attitudes towards Nature and the Environment. Cambridge Journal of Education, 28, 2-168

Bord, R. J., \& O'Connor, R. E. (1997). The gender gap in environmental attitudes: the case of perceived vulnerability to risk. Social Science Quarterly, 78(4), 830-840

Bott, S., Cantrill, J. G., \& MyersJr. and O.E (2003). Place and the promise of conservation psychology. Human Ecology Review, 10(2), 100-112

Bozdemir, H., \& Faiz, M. (2018). Ecocentric, anthropocentric and antipathetic attitudes of teacher candidates towards the environment. Sakarya University Journal of Education, 8(1), 61-75. https://doi.org/ 10.19126/suje.330546.

Brady, H., Schlozman, K. L., \& Verba, S. (1999). Prospecting for participants: Rational expectations and the recruitment of political activists. American Political Science Review, 93, 153-168

Brown, G., Smith, C., Alessa, L., \& Kliskey, A. (2004). A comparison of perceptions of biological value with scientific assessment of biological importance. Applied Geography, 24, 161-180

Burger, J., Sanchez, J. W., \& Gochfeld, M. (1998). Gender differences in recreational use, environmental attitudes, and perceptions of future land use at the Savannah River Site. Environment Behavior, 30, $472-486$

Cantril, H. (1934). Attitudes in the making. Understanding the Child, 4, 13-15

Cara, L., Booker, Yvonne, J., \& Kelly and Amanda Sacker (2018). Gender differences in the associations between age trends of social media interaction and well-being among 10-15-year-olds in the UK. BMC Public Health, 2-12. https://doi.org/10.1186/s12889-018-5220-4.

Çavuşoğlu, F., Altay, B., Nuriyeva, G., \& Öngör, B. (2017). Analysis of environment knowledge and attitudes of the primary school students. Journal of Anatolia Nursing and Health Sciences, 20(4), 254-259

Çetinkaya, G. (2015). Are environmental attitudes affected by outdoor sports participation? A study on university students. Spormetre Journal of Physical Education and Sport Sciencess, 13(2), 137-142

Chauhan, N. B., Patel, J. B., Kumar, V., Saini, H., \& Gulkari, K. D. (2017). 2017.Scales to measure attitude towards various components of rural \& agricultural development. Gujarat Journal of Extension Education, Special issue on measurement of attitude: April

Chave, E. J. (1928). A new type scale for measuring attitudes. Relig. Educ, 23, 364-369

Chen, C. C. (2010). Spatial inequality in municipal solid waste disposal across regions in developing countries. International Journal of Environmental Science and Technology, 7(3), 447-456

Chen, H. W., Yu, R. F., Liaw, R. F. S. L. and, \& Huang, W. C. (2010). Information policy and management framework for environmental protection organization with ecosystem conception. International Journal of Environmental Science and Technology, 7(2), 313-326

Chen, Z., Ngo, H. H., Guo, W., Wang, X. C., Miechel, C., Corby, N., et al. (2013). Analysis of social attitude to the new end use of recycled water for household laundry in Australia by the regression models. Journal of Environmental Management, 126, 79-84. https://doi.org/10.1016/j.jenvman.2013.04.012.

Chenyang, X., \& Dayong, H. (2010). Gender differences in environmental behaviours in China. PopulationEnvironment, 32, 88-104

Chenyang Xiao, \& Aaron, M. M. C. (2015). Gender Differences in Environmental Concern: Revisiting the Institutional Trust Hypothesis in the USA. Environment and Behavior, 47, 17. doi:https://doi.org/10. $1177 / 0013916513491571$

Chikkatur, A. P., Sagar, A. D., \& Sankar, T. L. (2009). Sustainable development of the Indian coal sector. Energy, 34, 942-953

Choudary, R. (2005). Ecology and environment and pollution, definition, history and scholarship. Agrobios (India), Jodhpur, 1(10):14-15. Retrieved on March 17, 2016, from http://jcmc.ind 
Cihar, M., \& Stankova, J. (2006). Attitudes of stakeholders towards the Podyji/ThayaRiver Basin National Park in the Czech Republic. Journal of Environmental Management, 81(3), 273-285

Cook, A., Finkelman, R. B., \& Fourie, A. (2011). Mineral and fuel extraction: health consequences. Encyclopedia of Environmental Health, 23, 781-787

Cooper, A., McCann, T., \& Ballard, E. (2005). The effects of livestock grazing and recreation on Irish machair grassland vegetation. Plant Ecology, 181(2), 255-267

CPCB (Central Pollution Control Board) (2016). Central pollution control board (CPCB) bulletin, Goverment of India. Accessed 3 Dec 2016. https://cpcb.nic.in/openpdffile.php?id=TGF0ZXN0RmlsZS9 MYXRlc3RfMTIzX1NVTU1BUllfQk9PS19GUy5wZGY.

Creswell, J. W. (1994).Planning, Conducting and Evaluating Quantitative and Qualitative Research, Prentice Hall

Cucinotta, D., \& Vanelli, M. (2020). WHO Declares COVID-19 Pandemic. Acta Biomed, 91, 157-160

Dankelman, I. (2002). Gender and Environment: Lesson to Learn. Quality of Human Resources: Gender and indigenous people. Netherlands: Centre for Environmental Studies, University of Nijmegen

Davidson, D. J., \& Freudenburg, W. R. (1996). Gender and environmental risk concerns: a review and analysis of available research. Environment and Behavior, 28, 302-339. doi:https://doi.org/10.1177/00139 16596283003

Davis, J. (1998). Young children, environmental education, and the future. Early Childhood Education Journal, 26(2), 117-123

DesJardins, J. R. 2012.Environmental Ethics: An Introduction to EnvironmentalPhilosophy, Cengage Learning, Belmont, California, Calif, USA, 5th edition

Dietz, T., Kalof, L., \& Stern, P. C. (2002). Gender, values, and environmentalism. Social Science Quarterly, 1, 353-364. doi:https://doi.org/10.1080/08941929209380772

Dobson, K. (1997). Hopes for the future: Restoration ecology and conservation biology. Istanbul: TESEV publications

Donald, A., Lucy, C. J., \& Asghar, R. (1984). Introduction to research in education. Holt, Rinehart and Winston, Inc

Dowsley, M. (2009). Community clusters in wildlife and environmental management: using TEK and community involvement to improve co-management in an era of rapid environmental change. Polar Research, 28(1), 43-59

Driussi, C., \& Jansz, J. (2006). Pollution minimization practices in the Australian mining and mineral processing industries. Journal of Cleaner Production, 14(8), 673-681

Droba, D. D. (1933). The nature of attitude. Journal of Social Psychology, 4, 444-463

Dunlap, R. E., Liere, K. D. V., Mertig, A. G., \& Jones, R. E. (2000). Measuring endorsement of the new ecological paradigm: a revised NEP scale. Journal of Social Issues, 56(3), 425-442

Dzerefos, C. M., \& Witkowski, E. T. F. (2001). Density and potential utilization of medicinal grassland plants from Abe Bailey Nature Reserve, South Africa. Biodiversity and Conservation, 10(11), 1875-1896

Eagles, P., \& Demare, R. (1999).Factors influencing children's environmental attitudes

Eagly, A. H. (1987). Sex differences in social behaviour: A social role interpretation. Nueva Jersey: Erlbaum

Eisler, A. D., Eisler, H., \& Yoshida, M. (2003). Perception of human Ecology: Cross-cultural and gender comparisons. Journal of Environmental Psychology, 23(1), 89-101. https://doi.org/10.1016/S02724944(02)00083-Xhttp://dx.doi.org.proxy1.cl.msu.edu/

Ekborg, M. (2003). How student teachers use scientific conceptions to discuss a complex Environmental issue. Journal of Biological Education, 37(3), 126-132

Eliana Andréa Severo (Julio Cesar Ferro de Guimarães, Mateus Luan Dellarmeli, and Rossana Parizotto Ribeiro 2019). The Influence of Social Networks on Environmental Awareness and the Social Responsibility of Generations, BBR. https://doi.org/10.15728/bbr.2019.16.5.5

Emilio Abad-Segura, Francisco Joaquín Cortés-García and \& Belmonte-Ureña, L. J. (2019). The Sustainable Approach to Corporate Social Responsibility: A Global Analysis and Future Trends. Sustainability,11(19), 5382, https://doi.org/10.3390/su11195382

Ergas, C., \& York, R. (2012). Women's status and carbon dioxide emissions: a quantitative cross-national analysis. Social Science Research, 41(4), 965-976

Ergas, C., \& York, R. (2012). Women's status and carbon dioxide emissions: a quantitative cross-national analysis. Social Science Research, 41(4), 965-976. doi:10.1016/j. ssresearch.2012.03.008

Ewer, B. C. (1929). Social psychology. New York: MacmillanPp. ix +435

Fabricius, C., \& Burger, M. (1997). Comparison between a nature reserve and adjacent communal land in Xeric Succulent Thicket: an indigenous plant user's perspective. South African Journal of Science, 93(6), 259-262 
Failing, L., Gregory, R., \& Harstone, M. (2007). Integrating science and local knowledge in environmental risk management: a decision-focused approach. Ecological Economics, 64, 47-60

Fatih, A., Mücahit, C., Hüseyin, K., \& Erdönmez, D. (2011). Gifted students' attitudes towards environment: A case study from Turkey. African Journal of Agricultural Research, 6(7), 1876-1883. DOI: https://doi.org/10.5897/AJAR11.288

Fiallo, E. A., \& Jacobson, S. K. (1995). Local communities and protected areas: attitudes of rural residents towards conservation and Machalilla National Park. Ecuador.Environmental Conservation, 22(3), 277-292

Field, A. (2009). Discovering Statistics Using SPSS (3rd ed.). London: Sage Publications

Filippos Zachariou, I., Voulgari, E., \& Tsami, S. B. (2020). Exploring the Attitudes of Secondary Education Students on Environmental Education in Relation to their Perceptions on Environmental Problems: The Case of the Prefecture of Viotia. Interdisciplinary Journal of Environmental and Science Education, 16(1), 1-13

Fischer, A. (2010). On the role of ideas of human nature in shaping attitudes towards environmental governance. Human Ecology, 38, 123-135

Frank, L. D. (2000). Land use and transportation interaction: implications on public health and quality of life. Journal of Planning Education and Research, 20, 622

Frazier, B., Culley, J. M., Hein, L. C., Williams, A., \& Tavakoli, A. S. (2014). Social networking policies in nursing education. CIN: Computers, Informatics, Nursing, 32(3), 110-117

Fredriksson, P. G., \& Wang, L. (2011). Sex and environmental policy in the U.S. House of Representatives. Economics Letters, 113(3), 228-230. doi:https://doi.org/10.1016/j.econlet.2011.07.019

Freeman, R. (1997). Working for nothing: The supply of volunteer labour. Journal of Labor Economics, 15, $140-166$

Frumkin, H. (2002). Urban sprawl and public health. Public Health Reports, 117, 201-217

Gagandeep Kaur and Ritu Dang (2015). Attitude towards the environment of male and female senior secondary school students of different streams.GHG Journal of Sixth Thought, 2(1)

Gender Tool Box (2016).Gender and the Environment

Gerry, L., \& Aida, A. (2019). Comparison within gender and between female and male leaders in femaledominated, male-dominated and mixed-gender work environments. Journal of Gender Studies. DOI: https://doi.org/10.1080/09589236.2019.1638233

Gerry Larsson and Aida Alvinius. (2019). Comparison within gender and between female and male leaders in female-dominated, male-dominated and mixed-gender work environments. Journal of Gender Studies, 1-12. DOI: https://doi.org/10.1080/09589236.2019.1638233

Gidde, M. R., K. K. Kokate, and V. V. Todkar (2008). Municipal solid waste management in emerging mega cities: A case study of Pune City. In Proc., Indo Italian Conference on Green and Clean Environment (pp. 441-450). New Delhi, India: Daya Publishing House.

Giddings, B., Hopwood, B., \& O’Brien, G. (2002). Environment, economy and society: fitting them together into sustainable development. Sustainable Development, 10(4), 187-196. https://doi.org/10.1002/sd. 199.

Gigliotti, L. M. (1992). Environmental attitudes 20 Years of change. Journal of Environmental Education, 24(1), 15-26

Gilligan, C. (1982). In a different voice: Psychological theory and women's development. Cambridge, MA: Harvard University Press

Glasman, L. R., \& Albarracin, D. (2006). Forming attitudes that predict future behaviour: a meta-analysis of the attitude-behaviour relation.Psychological Bulletin,778-822

Gökçe, N., \& Sarıyar, S. (2019). Reasons for the differentiation of the attitudes of female and male students towards the environment: teachers and parents opinions. The Western Anatolia Journal of Educational Sciences, 10(2), 131-145

Gore, A. (1993). Earth in the Balance: Ecology and The Human Spirit. Boston, MA: Houghton- Mifflin

Graham, H., Mason, R., \& Newman, A. (2009). Literature Review: Historic Environment, Sense of Place, and Social Capital. English Heritage, UK, pp. 44

Greenbaum, A. (1995). Taking stock of two decades of research on the social bases of environmental concern. In Mehta, M. D., \& Ouellet, E. (Eds.), Environmental sociology (pp. 125-152). North York, Ontario, Canada: Captus Press

Grodzinska-Jurzcak, M., Stepska, A., Nieszporek, K., \& Bryda, G. (2006). Perception of environmental problems among pre-school children in Poland. International Research in Geographical and Environmental Education, 15(1), 62-76. https://doi.org/10.2167/irgee187.0.

Gulcin Yapici, O., \& Ögenler, Ahmet Öner Kurt, FazJl KoçaGand Tayyar FaGmaz1 2017. Assessment of Environmental Attitudes and Risk Perceptionsamong University Students in Mersin, Turkey.Hindawi Journal of Environmental and Public Healthhttps://doi.org/10.1155/2017/5650926 
Gulcin Yapici, O., \& Ögenler, A. (2017). Assessment of Environmental Attitudes and Risk Perceptions among University Students in Mersin, Turkey. Journal of Environmental and Public Health. Article ID, 5650926. https://doi.org/10.1155/2017/5650926Öner Kurt,1 FazIL KoçaS and Tayyar FaGmaz

Gupta, B., \& Arora, S. K. (2016). Municipal solid waste management in Delhi-The Capital of India. The International Journal of Innovative Research in Science, Engineering and Technology, 54(4), 5130-5138.

Gustafson, P. E. (1998). Gender differences in risk perception: Theoretical and methodological perspectives. Risk Analysis, 18, 805-811

Haartman, R. V., Sammalisto, K., Lozano, R., \& Blomqvist, P. (2017). A longitudinal comparison of sustainability learning between men and women in engineering and nursing programmes. Sustainability, $9(8), 1-10$

Handy, S. L., Boarnet, M. G., Ewing, R., \& Killingsworth, R. E. (2002). How the builtenvironment affects physical activity: views from urban planning. American Journal of Preventive Medicine, 23, 64-73

Haski-Leventhal, D. (2009). Elderly volunteering and well-being: A cross-European comparison based on SHARE data. International Journal of Voluntary and Non-profit Organizations, 20, 388-404

Hayes, B. C. (2001). Gender, scientific knowledge, and attitudes toward the environment: A cross-national analysis. Political Research Quarterly, 54(3), 657-671

Hernandez, O., Rawlins, B., \& Schwartz, R. (1999). Voluntary recycling in Quito: factors associated with participation in a pilot programme. Environment and Urbanization, 11(2), 145-159

Hicks, C. C., McClanahan, T. R., Cinner, J. E., \& Hills, J. M. (2009). Trade-offs in values assigned to ecological goods and services associated with different coral reef management strategies. Ecology and Society 14 (1): 10 (online) URL: http://www.ecologyandsociety.org/vol14/iss1/art10/

Himmelfarb, S. (1993). The measurement of attitudes. In A. H. Eagly \& S. Chaiken (Eds.), The psychology of attitudes. Harcourt Brace Javanovich: Orland, FL.

Hitchcock, J. L. (1995). Centralization, resource depletion, and coercive conservation among the Tyua of the Northeastern Kalahari. Human Ecology, 23(2), 169-198

Hong, Z., Jie, S., \& Chao, S., Mengying (2013). Human attitudes in environmental management: Fuzzy Cognitive Maps and policy option simulations analysis for a coal-mine ecosystem in China. Journal of Environmental Management, 115, 227-234

Hong, D. Y., \& Xiao, C. Y. (2007). Gender and environmental concern in China. Sociological Studies(Chinese), (2), 111-135. https://doi.org/10.1027/1015-5759.21.2.128

Huhtala, A. (1999). How much do money, inconvenience and pollution matter? Analysing households' demand for large-scale recycling and incineration. Journal of Environmental Management, 55, 27-38

Hustinx, L., \& Lammertyn, F. (2003). Collective and reflexive styles of volunteering: A sociological modernization perspective. International Journal of Voluntary and Non-profit Organizations, 14, 167-187

Ifegbesan, A. (2010). Exploring secondary school students' understanding and practices of waste management in Ogun State, Nigeria. International Journal of Environment and Science Education, $5(2), 201-215$

Infield, M. (1988). Attitudes of a rural community towards conservation and local conservation in Natal, South Africa. Biological Conservation, 45, 21-46

Institute of Medicine, 2001. Exploring the biological contributions to human health. In: T. M. Wizeman \& M.-L. Pardue (Eds.), Does Sex Matter? National Academy Press, Washington, DC

Ite, U. E. (1996).Community Perceptions of the Cross River National Park, Nigeria

Jackson, C. (1993). Doing what comes naturally? Women and environment in development. World Development, 21(12), 1947-1963

Jerry, A. N. (2015). Solid Waste Management. New York: Encyclopedia Britannica, Inc

Jing, L., Zhiyun, O., \& Miao, H. (2010). Environmental attitudes of stakeholders and their perceptions regarding protected area-community conflicts: A case study in China. Journal of Environmental Management, 91, 2254-2262

Kadam, J. R., Patil, V. G., Dhenge, S. A., \& Murai, A. M. (2017). Communication Skills and Personality Development. Rajasthan: Scientific Publisher, Jodhpur

Kağıtçıbaşı, C., Sunar, D., \& Bekman, S. (2001). Long-term effects of early intervention: Turkish lowincome mothers and children. Applied Developmental Psychology, 22, 333-361

Kals, E. D., Schumacher, \& Montada, L. (1999). Emotional affinity toward nature as a 36motivational basis to protect nature. Environment and Behavior, 31, 178-202

Kaltenborn, B. P. (1998). Effects of the sense of place on responses to environmental impacts. Applied Geography, 18(2), 169-189

Kaplan, A. M., \& Haenlein, M. (2010). Users of the world, unite! The challenges and opportunities of Social Media. Business Horizons, 53(1), 59-68 
Kara, K. W., \& Chan (1996). Environmental attitudes and behaviour of secondary school students in Hong Kong. The Environmentalist, 16, 297-306

Karaçar, E. (2016). The effect of attitudes towards environment and destination image on re-visit intention in recreational activities: Sample of Ilgaz Mountain National Park [Unpublished doctoral dissertation]. Gazi University

Karasar, N. (2007). Bilimsel Arastirma Yöntemi. Ankara: Nobel Yayin Dagitim.

Kerlinger, F. N. (1956). Foundations of Behavioral Research. 2nd edition. Holt, Rinehart and Winston

Kerlinger, F. H. (1964). Foundations of behavioural Research: Educational and Psychological Inquiry. New York: Holt, Rinehart \& Winston.

Kietzmann, J. H., Hermkens, K., McCarthy, I. P., \& Silvestre, B. S. (2011). Social media? Get serious! Understanding the functional building blocks of social media. Business Horizons, 54(3), 241-251

Kim, K. O. (2003). An inventory for assessing environmental education curricula. The Journal of Environmental Education, 34(2), 12-18

Kishor, A. (2007). Short communication Pesticide use knowledge and practices: A gender differences in Nepal. Environmental Research, 104, 305-311

Kose, A. N. 2015. Environment Awareness and attitude towards Environment of Male and Female class v students of Chandigarh, Haryana and Punjab P.U. Department of Education, M.Ed. Dissertation

Krosnick, J. A., Judd, C. M., \& Wittenbrink, B. (2005). The measurement of attitudes. In D. Albarracín, B. T. Johnson, \& M. P. Zanna (Eds.), The handbook of attitudes (pp. 21-76). Mahwah, NJ: Lawrence Erlbaum.

Kuldeep, S. K. (2016). Awareness and attitude of school students towards environment.Scholarly Research Journal for Interdisciplinary Studies, 8543-8550

Kuldeep, S. K. (2017). Awareness and Attitude of School Students towards Environment. Scholarly Research Journal for Interdisciplinary Studies, 4(37), 543-855. https://doi.org/10.21922/srjis. v4i37.10672

Larson, S. (2011). From Individual Wellbeing to Regional Priorities: Concepts and Measures to Assist Policy Makers (p. 180). Newcastle upon Tyne: Cambridge Scholars Publishing

Leach, M. (1991). Gender and the Environment: Traps and Opportunities. Paper prepared for Development Studies Association (DSA) conference, Swansea, September 11-13. Institute of Development Studies, Brighton

Lee, Eunsil, \& Nam Kyu Park and Ju Hyoung Han. (2013). Gender Difference in Environmental Attitude and Behaviors in Adoption of Energy-Efficient Lighting at Home. Journal of Sustainable Development, 6(9), 36-50

Lee, E., Park, N. K., \& Han, J. H. (2013). Gender differences in environmental attitude and behaviours in the adoption of energy-efficient lighting at home. Journal of Sustainable Development, 6, 36-50

Leton, T. G., \& Omotosho, O. (2004). Landfill operations in the Niger Delta region of Nigeria. Engineering Geology, 73(1-2), 171-117

Lewis, A. E., Hammill, M. O., Power, M., Doidge, D. W., \& Lesage, V. (2009). Movement and aggregation of eastern Hudson Bay Beluga Whales (Delphinapterusleucas): a comparison of patterns found through satellite Telemetry and Nunavik traditional ecological knowledge. Arctic, 62 (1):13-24

Li, F., Wang, R., Paulussen, J., \& Liu, X. (2005). Comprehensive concept planning of urban greening based on ecological principles: a case study in Beijing. China Landscape and Urban Planning, 72, 325-336

Li, G. Y., \& Zhou, W. F. (2006). Impact of karst water on coal mining in North China. Environmental Geology, 49, 449-457

Little Flower, D. (2006). A Study of Environmental awareness and ethics of Higher Secondary Students in Pondicherry. Unpublished M.Phil. Thesis, Anna Malai University, Coimbatore

Luna, M., Aguilar, L., Gilligan, M., Owren, C., Prebble, M., \& Westerman, K. (2015). Women in environmental decision making: Case studies in Ecuador, Liberia, and the Philippines. The Global Gender Office of IUCN, in collaboration with Conservation International

Lundberg, G. A. (1929). Social research. New York: Longmans, GreenPp. x +379.

Mackey, G. (2012). To know, to decide, to act: The young child's right to participate in activities for the environment. Environmental Education Research, 18(4), 473-484. https://doi.org/10.1080/13504622. 2011.634494

Manoa David Owino Gender and Environmental Management: Who's Role? Whose Responsibilities?World Journal of Social Sciences and Humanities, 3 (30):61-63(DOI:https://doi.org/10.12691/wjssh-3-3-2)

Marita, W. O., Eriksson, I. D., \& PatrikSörqvist (2018). Gender Differences in Environmental Perspectivesamong Urban Design Professionals. Buildings, 8, 59. doi:https://doi.org/10.3390/buildings8040059

McCright, A. M., \& Dunlap, R. E. (2011). The politicization of climate change and polarization in the American public's views of global warming, 2001-2010. Sociological Quarterly, 52, 155-194

McQuail, D. (1994). Mass communication theory. An introduction. London: Sage publication 
McStay, J. R., \& Dunlap, R. E. (1983). Male-female differences in concern for the environment. Journal of Environmental Education, 30, 33-37

Mehta, J. N., \& Kellert, S. R. (1998). Local attitudes towards community-based conservation and programmes in Nepal: a case study of the Makalu-Barunconservation area. Environmental Conservation, 25(4), 320-333

Meinzen-Dick, R., Kovarik, C., \& Quisumbing, A. R. (2014). Gender and Sustainability. Annual Review of Environment and Resources, 39(1), 29

Merce Roca, I. P., Silvia, A., Alba, B., \& Pere, F. (2020). What factors determine attitudes towards the implementation of a packaging deposit and refund system- A qualitative study of the perception of Spanish consumers. Journal of Environmental Management, 270, 1-10

Milfont, T. L., \& Duckitt, J. (2004). The structure of environmental attitudes: a first-and second-order confirmatory factor analysis. Journal of Environmental Psychology, 24(3), 289-303

Mishra, C. (1997). Livestock depredation by large carnivores in the Indian trans-Himalaya: conflict perceptions and conservation prospects. Environmental Conservation, 24(4), 338-343

Misra, S., \& Panda, R. K. (2017). Environmental consciousness and brand equity. An impact assessment using the analytical hierarchy process (AHP). Marketing Intellectual Planning, 35, 40-61

Mohai, P. (1992). Men, women, and the environment: an examination of the gender gap in environmental concern and activism. Society and Natural Resources, 5, 1-19. doi:https://doi.org/10.1080/08941 929209380772

Mohai, P. (1997). Gender differences in the perceptions of most important environmental problems. Race, Gender, and Class, 5, 153-169

Morgan, J. J. B. (1934). Keeping a sound mind. New York: MacmillanPp. ix +440.

Moseley, C. (2000). Teaching for environmental literacy. Clearing House, 74(1), 23-25

Müderrisoglu, H., \& Altanlar, A. (2011). Attitudes and behaviours of undergraduate students toward environmental issues. International Journal of Environmental Science and Technology, 8(1), 159-168

Müderrisolu, H., \& Altanlar, A. (2011). Attitudes and behaviours of undergraduate students towards environmental issues. International Journal of Environment Science and Technology, 8(1), 159-168

Müderrisolu, H., \& Altanlar, A. (2011). Attitudes and behaviours of undergraduate students toward environmental issues. International Journal of Environmental Science and Technology, 8(1), 159-168

Mujer con Éxito. The Instrumentality and Expressiveness in the Perception of Successful Women.Acta de Investigacion Psicologica, 4:1430-1445

Munasinghe, M. (2020). COVID-19 and sustainable development. International Journal of Sustainable Development, 23(1/2), 1-24. https://doi.org/10.1504/ijsd.2020.112182.

Mustafa Özden. (2008). Environmental Awareness and Attitudes of Student Teachers: An Empirical Research. International Research in Geographical and Environmental Education, 17(1), 40-55. DOI: https://doi.org/10.2167/irgee227

Mustard, F. (2000). Early childhood development: The base for a learning society. Paper presented at the HRDC/OECD Meeting, Ottawa, Canada

Nagra, V. (2010). Environmental education awareness among school teachers. The Environmentalist, 30(2), 153-162

NBSC. (2016). China Statistical Yearbook. Beijing: China Statistics Press

Negev, M., Garb, Y., Biller, R., Sagy, G., \& Tal, A. (2010). Environmental problems, causes, and solutions: an open question. The Journal of Environmental Education, 4(2), 101-115

Nesenur Altinigne and F. Zeynep Bilgin 2015.The Effect of Environmental Attitudes on Environmentally Conscious Behavior of University Students, conference paper

Newmark, W., \& Hough, J. (2000). Conserving wildlife in Africa: Integrated conservation and development projects and beyond. BioScience, 50(7), 585-592

Newmark, W. D., Leonard, N. L., Sariko, H. I., \& Gamassa, D. G. M. (1993). Conservation attitudes of local people living adjacent to Five protected areas in Tanzania. Biological Conservation, 63, 177-183

Nierenberg, D. (2002). Correcting gender myopia: gender equity, women's welfare, and the environment. World Watch Paper, 161, 5-68

Nouri, J., Karbassi, A. R., \& Mirkia, S. (2008). Environmental management of coastal regions in the Caspian Sea. International Journal of Environment and Science and Technology, 5(1), 43-52

Nouri, J., Karbassi, A. R., \& Mirkia, S. (2008). Environmental management of coastal regions in the Caspian Sea. International Journal of Environmental Science and Technology, 5(1), 43-52

Nutbrown, C. (2006). Key concepts in early childhood education care. New York: Sage Publications Psychology Press

Aasa, O. P., Ajayi, O. M., \& Oluwaseun, V. O. O., Tope Akinbogun (2019). Stakeholders' Participation in Environmental Management in the Nigerian University System: Gender Perspective. Journal of Economics and Sustainable Development, 10(24), 95-102 
Oliveira, R., \& Anderson, S. E. (1999). Gender, Conservation and Community participation: the Case of Jau National Park, Brazil. Florida, University of Florida

Osterberg, M. J. (1996). Gender in supervision: exaggerating the differences between men and women. The Clinical Supervisor, 14, 69-83

Özpinar, D. (2009). Ilkögretim 4. ve 5. Sinif Ogrencilerinin Cevre Sorunlari Hakkindaki Görüsleri (Afyonkarahisar Đli Örnegi).Yayimlanmamis Yüksek Lisans Tezi, Afyon Kocatepe Üniversitesi. Afyonkarahisar: Sosyal Bilimler Enstitüsü

Parry, D., \& Campbell, B. (1992). Attitudes of rural communities to animal wildlife and its utilization in Chobe Enclave and Mababe Depression, Botswana. Environmental Conservation, 19(3), 245-251

Pelstring, L. (1997). Measuring environmental attitudes: The new environmental paradigm. Retrieved from www.docstoc.com/docs/20845968/Environmental-Attitude

Pérez-Franco, D., Pro-Bueno, A. J., \& Pérez-Manzano, A. (2018). Do environmental attitudes change in secondary education? A diagnostic study with Secondary students from Murcia. Rev. Eureka Sobre Ensen. Divulg. Cienc, 15, 3501

Peters, J. (1998). Transforming the integrated conservation and development project(ICDP) approach: observations from the Ranomafana National Park Project, Madagascar. Journal of Agricultural \& Environmental Ethics, 11(1), 17-47

Pham, T. T. N., Ngo, H. H., Guo, W. S., Dang, H. P. D., Mainali, B., Johnston, A., \& Listowski, A. (2011). Response of community to the public use of recycled water for washing machine: a case study in Sydney. Australia. Resource Conservation Recycling, 55, 535

Pimm, S. L., Russel, G. J., Gittleman, J. L., \& Brooks, T. M. (1995). The future of biodiversity. Science, 269, 347-350

Polonsky, M. J., Garma, R., \& Grau, S. L. (2011). Western consumers' understanding of carbon offsets and its relationship to behaviour. Asian Pacific Journal of Marketing Logistics, 23, 583-603

Polonsky, M. J., Vocino, A., Grau, S. L., Garma, R., \& Ferdous, A. S. (2012). The impact of general and carbon-related environmental knowledge on attitudes and behaviour of US consumers. Journal of Marketing Management, 28, 238-263

Potapov, P., Laestadius, L., \& Minnemeyer, S. (2011). Global Map of Forest Condition. Online at. World Resources Institute, Washington, DC. www.wri.org/ forest-restoration-atlas, Accessed date: 22 July 2017

Pote, J., Shackleton, C., Cocks, M., \& Lubke, R. (2006). Fuelwood harvesting and selection in Valley Thicket, South Africa. Journal of Arid Environments, 67(2), 270-287

Pouria Ataei, V., Aliabadi, A., \& Norouzi, H. S. (2018). Measuring the employees' environmental attitude of agricultural knowledge-based companies based on sociocultural components: a case study from Iran. Journal of Environmental Developmental and Sustainability. https://doi.org/10.1007/ s10668-018-0136-9.

Power, A. (2001). Social exclusion and urban sprawl: is the rescue of cities possible. Regional Studies, $35,731-742$

Pressey, R. L., \& Bottrill, M. C. (2008). Opportunism, threats, and the evolution of systematic conservation planning. Conservation Biology, 22(5), 1340-1345

Pressey, R. L., Cabeza, M., Watts, M. E., Cowling, R. M., \& Wilson, K. A. (2007). Conservation planning in a changing world. Trends in Ecology \& Evolution, 22(11), 583-592

Rada, E. C., Ragazzi, M., \& Fedrizzi, P. (2013). Web-GIS oriented systems viability for municipal solid waste selective collection optimization in developed and transient economies. Waste Management, 33, 785-792

Rai, A. K., Paul, B., \& Singh, G. (2010). A study on the Bulk density and its effect on the growth of selected grasses in coal mine overburden dumps, Jharkhand, India. International Journal of Environment Sciences, 1(4), 677-684

Raju, G. (2007). Environmental Ethics of Higher Secondary Students in the schools of Cuddalore district, Tamil Nadu. In NCERT Journals, 6(11), 32-35

Rao, K. S., Maikhuri, R. K., Nautiyal, S., \& Saxena, K. G. (2002). Crop damage and livestock depredation by wildlife: a case study from Nanda Devi Biosphere Reserve, India. Journal of Environmental Management, 66(3), 317-327

Rauch, F. (2002). The potential of education for sustainable development for reform in schools. Environment Education and Research, 8(1), 43-51. https://doi.org/10.1080/13504620120109646

Rauniar, R., Rawski, G., Yang, J. Y., \& Johnson, B. (2014). Technology acceptance model (TAM) and social media usage: an empirical study on Facebook. Journal of Enterprise Information Management, 27(1), 6-30 
Rawat, M., Ramanathan, A. L. \& Kuriakose, T. (2013). Characterisation of municipal solid waste compost (MSWC) from selected Indian Cities: A case study for its sustainable utilisation. Journal of Environment Protection, 4(2), 163-171. https://doi.org/10.4236/jep.2013.42019.

Raymond, C., \& Brown, G. (2006). A method for assessing protected area allocations using a typology of landscape values. Journal of Environmental Planning and Management, 49(6), 797-812

Refsgaard, K., \& Magnussen, K. (2009). Household behaviour and attitudes with respect to recycling food waste experiences from focus groups. Journal of Environmental Management, 90, 760-771

Reingold, B. (2000). Representing women: sex, gender, and legislative behaviour in Arizona and California. Chapel Hill, NC: University of North Carolina Press

Robinson, G. M., \& Read, A. D. (2005). Recycling behaviour in London Borough: results from largescale household surveys. Resources Conservation and Recycling, 45(1), 70-83

Robinson, J. (2004). Squaring the circle? Some thoughts on the idea of sustainable development. Ecology and Economics, 48(4), 369-384. https://doi.org/10.1016/j.ecolecon.2003.10.017.

Sagır, S., Aslan, O., \& Cansaran, A. (2008). Ilkögretim Ogrencilerinin Cevre Bilgisi ve Cevre Tutumlarinin Farklı Degiskenler Acisindan Đncelenmesi. Ilkögretim Online E-Dergi, 7(2), 496-511

Sahin, H., \& Erkal, S. (2010). The attitudes of middle school students towards the environment. Social Behavior and Personality: An international journal, 38(8), 1061-1072

Sahu, S., Nair, S. J., \& Sharma, P. K. (2014). Review on solid waste management practice in India: A state of art. International Journal of Innovative Research \& Development, 3(3), 261-264.

Sarkar, M. (2011). Secondary students' environmental attitudes: the case of environmental education in Bangladesh. International Journal of Academic Research in Business and Social Sciences, 1(3 Special), 96-109

Schultz, P. W., Nolan, J. M., Cialdini, R. B., Goldstein, N. J., \& Griskevicius, V. (2007). The Constructive, Destructive, and Reconstructive Power of Social Norms. Psychological Science, 18(5), 429-434

Sekhar, N. U. (2003). Local people's attitudes towards conservation and wildlife tourism around Sariska Reserve, India. Journal of Environmental Management, 69, 339-347

Sendil, M., \& Sethuraman, K. (2017). Hypothesis Development and Testing. Journal of Business and Management, 19: (5)34-40 Seth, J. N., Sethia, N. K., Srinivas, S. 2011. Mindful consumption: a customer-centric approach to sustainability. Journal of Academic Marketing Science, 39: 21-39

Sharholy, M., Ahmad, K., Mahmood, G., \& Trivedi, R. C. (2008). Municipal solid waste management in Indian cities: A review. Waste Management, 28(2), 459-467. https://doi.org/10.1016/j.wasman.2007. 02.008.

Sherkat, D. E., \& Ellison, C. G. (2007). Structuring the religion-environment connection: Identifying religious influences on environmental concern and activism. Journal of the Scientific Study of Religion, 46(1), 71-85

Shettima, A. G. (1996). Gender Issues in Monitoring the Environment: The case of Rural Nigeria. A paper presented at the 39th Annual Conference of the Nigerian Geographical Association, 5th -8th May, at the University of Maiduguri

Si, H., Bi, H., Li, X. H., \& Yang, C. H. (2010). Environmental evaluation for sustainable development of coal mining in Qijiang, Western China. International Journal of Coal Geology, 81, 163-168

Silva, L., Debora, M., De, F., \& Christina, C. H. (2013). Sense of place as a determinant of people's attitudes towards the environment: Implications for natural resources management and planning in the Great Barrier Reef, Australia. Journal of Environmental Management, 117, 226-234

Singh, R. P., Tyagi, V. V., Allen, T., Ibrahim, M. H., \& Kothari, R. (2011). An overview for exploring the possibilities of energy generation from municipal solid waste (MSW) in Indian scenario. Renewable and Sustainable Energy Reviews, 15(9), 4797-4808. https://doi.org/10.1016/j.rser.2011.07.071.

Sivamoorthy, M., Nalini, R., \& Satheesh, K. (2013). Environmental awareness and practices among college students. International Journal of Humanities and Social Science Invention, 2(8), 2319-7722

Smyth, C., \& Dearden, P. (1998). Attitudes of environmental management personnel involved in surface coal mine reclamation in Alberta and British Columbia, Canada. Geography, 18(3), 275-295

Soma, C. (2020). Addressing gender issues and actions in biodiversity objectives. Convention on biological diversity

Song, J., Zhang, H., \& Li, F. (2010). Study on the environmental risk of coal-mining ecological models based on fuzzy cognitive-map. China Population Resources and Environment, 20(3), 142-145

Spodek, B. (1993). The handbook of research on education. New York: Teachers College Press

Steinmetz, R., Chutipong, W., \& Seuaturien, N. (2006). Collaborating to conserve large mammals in Southeast Asia. Conservation Biology, 20(5), 1391-1401

Stern, P. C., Dietz, T., \& Kalof, L. (1993). Value orientations, gender and environmental concern. Environment and Behaviour, 25(5), 322-348. doi:https://doi.org/10.1177/0013916593255002 
Stern, P., Dietz, T., \& Guagnano, G. (1995). The new ecological paradigm in a social psychological context. Environment and Behavior, 27(6), 723

Stevenson, R., Brody, M., Dillon, J., \& Wals, A. (2013). International Handbook of Research on Environmental Education. American Educational Research Association. https://doi.org/10.4324/9780203813331

Sundara Selvan, T. (2005). A study on Environmental Ethics among the Secondary pupils of Gudaloor District. Unpublished M.Phil. Thesis, Anna Malai University, Coimbatore

Taniguchi, H. (2006). Men's and women's volunteering: Gender differences in the effects of employment and family characteristics. Nonprofit and Voluntary Sector Quarterly, 35, 83-101

Tarrant, M. A., \& Cordell, H. K. (1997). The effect of respondent characteristics on general environmental attitude-behaviour correspondence. Environmental Behaviour, 29, 618-637

Tarrant, M. A., \& Cordell, H. K. (1997). The effect of respondent characteristics on general environmental attitude-behaviour correspondence. Environment Behavior, 29, 618-637

Thapa, B. (1999). Environmentalism: The relation of environmental attitudes and environmentally responsible behaviours among undergraduate students. Bulletin of Science, Technology \& Society, 19(5), 426-438

Thompson, J. C., \& Gasteiger, E. L. (1985). Environmental attitude survey of university students: 1971 vs 1981. Journal of Environmental Education, 17(1), 13-22

Tikka, P. M., Kuitunen, M. T., \& Tynys, S. M. (2000). Effects of educational background on students' attitudes, activity levels, and knowledge concerning the environment. The Journal of Environmental Education, 31(3), 12-19

Tindall, D. B., Davies, S., \& Mauboules, C. (2003). Activism and conservation behaviour in an environmental movement: The contradictory effects of gender. Society and Natural Resources, 16, 909-932

Tonglet, M., Phillips, P. S., \& Bates, M. P. (2004). Determining the drivers for household pro-environmental behaviour: waste minimization compared to recycling. Resources, Conservation and Recycling, 42, $27-48$

Tremblay, M. (1998). Do female MPs substantively represent women: A study of legislative behaviour in Canada's 35th parliament. Canadian Journal of Political Science, 31, 435-465. doi:https://doi.org/10.1017/ S0008423900009082

Tuncer, G., Sungur, S., Tekkaya, C., \& Ertepınar, H. (2004). Environmental Attitudes of the 6th Grade Students From Rural and Urban Areas: A Case Study for Ankara. Hacettepe Universitesi Egitim Fakültesi Dergisi, 26, 167-175

Turtle, C., Convery, I., \& Convery, K. (2015). Forest schools and environmental attitudes: A case study of children aged 8-11 years. Cogent Education, 2(1), 1100103

UN (2018). Sustainable Development Goals. 17 Goals to Transform Our World. New York, USA. http://www. un.org/sustainabledevelopment/development-agenda/, Accessed date: 4 March 2018

United Nations Environmental Programme (UNEP). (2011). Towards a green economy. Pathway to Sustainable Development and Poverty Eradication. Nairobi: United Nations

United Nations (2007). State of World Population 2007: Unleashing the Potential ofUrban Growth. New York: UN. Available at: http://www.unfpa.org/swp/2007/presskit/pdf/sowp2007_eng.pdf (accessed August 2008)

United Nations, U. N. (2016). Working Arrangements for the 2016 Session of the Economic and Social Council, 24 July 2015-27 July 2016. Retrieved from. on May 8th, 2017. www.un.org/ecosoc/en/sustainabledevelopment

The United States Environmental Protection Agency. (2000). Our Built and Natural Environments: a Technical Review of the Interactions between land Use, Transportation and Environmental Quality. Development, Community, and Environment. Washington, DC: US EPA

Uzun, N. (2007). Ortaöğretim Ogrencilerinin Cevreye Yönelik Bilgi ve Tutumlari Üzerine Bir Calisma. Yayinlanmamis Doktora Tezi. Hacettepe Üniversitesi, Fen Bilimleri Enstitüsü, Ankara

Van Metre, P. C., Mahler, B. J., \& Furlong, E. T. (2000). Urban sprawl leaves its PAHsignature. Environmental Science \& Technology, 34, 4064-4070

Venter, O., Sanderson, E. W., Magrach, A., Allan, J. R., Beher, J., Jones, K. R. ... Watson, J. E. M. (2016). Sixteen years of change in the global terrestrial human footprint and implications for biodiversity conservation. National Communication, 7, 12558

Vlaardingerbroek, V., \& Neil Taylor, T. G., T. G (2007). The environmental knowledge and attitudes of prospective teachers in Lebanon: A comparative study. International Research in Geographical and Environmental Education, 16(2), 120. 134.1

Walpole, M. L., \& Goodwin, H. J. (2001). Local attitudes towards conservation and tourism around Komodo National Park, Indonesia. Environmental Conservation, 28(2), 160-166

Wangnerud, L. (2000). Testing the politics of presence: women's representation in the Swedish Riksdag. Scandinavian Political Studies, 23(1), 67-91. doi:https://doi.org/10.1111/1467-9477.00031

Warren, F. C. (Ed.). (1934). Dictionary of psychology. Boston: Houghton MifflinPp. ix + 372. 
Watson, K., \& Halse, C. M. (2005). Environmental attitudes of pre-service teachers: a conceptual and methodological dilemma in cross-cultural data collection. Asia Pacific Education Review, 6(1), 59-71

Weladji, R. B., Stein, R. M., \& Vedeld, P. (2003). Stakeholder attitudes towards wildlife policy and the Bonoe wildlife conservation area, North Cameroon. Environmental Conservation, 30(4), 334-343

Wezel, A., \& Bender, S. (2004). Degradation of agro-pastoral village land in semi-arid southeastern Cuba. Journal of Arid Environments, 59(2), 299-311

Wilson, R. (1996). Environmental education programs for preschool children. The Journal of Environmental Education, 27(4), 28-33

Wilson, R. A. (1996). Starting early: Environmental education during the early childhood years. Journal of Wildlife Rehabilitation, 23(2), 23-25

Wolfe, J., \& Brandt, R. (1998). What we know from brain research. Quarterly Educational Leadership, 56(3), $8-14$

World Bank. (2002). Integrating Gender into the World Bank's Work. A Strategy for Action

WtR (Waste to Resources). 2014. Waste to resources: A waste management handbook. New Delhi, India: Energy and Resource Institute.

Xiao, C., \& McCright, A. M. (2013). Gender differences in environmental concern: revisiting the institutional trust hypothesis in the USA. Environment and Behavior, DOI:. doi:https://doi.org/10.1177/0013916513 491571

Xiao, C., \& Hong, D. (2010). Gender differences in environmental behaviours in China. Population and Environment, 32, 88-104

Xiao, C., \& McCright, A. M. (2012). Explaining gender differences in concern about environmental problems in the United States. Society and Natural Resources, 25, 1067-1084

Xiao, C., \& McCright, A. M. (2014). A test of the biographical availability argument for gender differences in environmental behaviours. Environment and Behavior, 46, 241-263

Yang, Z., \& Zhang, W. (2003). Current biodiversity situation of enlarged Nature ReserveofXishuangbanna and exploration of community co-management. Forest Inventory and Planning, 28(4), 27-31. (in Chinese).

Young, J., Watt, A., Nowicki, P., Alard, D., Clitherow, J., Henle, K. ... Richards, J., C (2005). Towards sustainable land use: identifying and managing the conflicts between human activities and biodiversity conservation in Europe. Biodiversity and Conservation, 14(7), 1641-1661

$\mathrm{Yu}$, B. (2005). Study on the establishment of community villagers self-organizationinXishuabanna Nature Reserve. Forest Inventory and Planning, 30(4), 119-121. (in Chinese).

Zelezny, L., Chua, P., \& \&Aldrich, C. (2000). Elaborating on gender differences in environmentalism. Journal of Social Issues, 56:443-457.

Publisher's Note Springer Nature remains neutral with regard to jurisdictional claims in published maps and institutional affiliations. 